\title{
Melanoma Immunotherapy: Overcoming Obstacles to Augment Anti-Tumor Immune Responses
}

\author{
Kristian M. Hargadon \\ Department of Biology, Hampden-Sydney College, Hampden-Sydney, USA. \\ Email:khargadon@hsc.edu \\ Received March $4^{\text {th }}, 2013$; revised April $6^{\text {th }}, 2013$; accepted April 13 ${ }^{\text {th }}, 2013$ \\ Copyright (C) 2013 Kristian M. Hargadon. This is an open access article distributed under the Creative Commons Attribution License, \\ which permits unrestricted use, distribution, and reproduction in any medium, provided the original work is properly cited.
}

\begin{abstract}
Melanoma is the most aggressive form of skin cancer and accounts for the vast majority of skin cancer-related deaths. Its ability to metastasize quickly, often before diagnosis, makes this cancer difficult to treat with traditional therapies. The identification of anti-melanoma immune responses in patients and the discovery of tumor antigens targeted by these immune responses have paved the way for immunotherapy as a novel approach to treating this cancer. In this review, the major immunotherapies targeting these melanoma tumor antigens are discussed. The advantages and limitations of peptide-, protein-, and gene-based vaccination maneuvers and adoptive cell transfer therapies are emphasized. Recent insights into melanoma immune evasion strategies are also highlighted, with particular focus on how our increasing knowledge of tumor/immune cell interactions is driving the development of novel immunotherapeutic strategies for the treatment of melanoma.
\end{abstract}

Keywords: Melanoma; Tumor Immunotherapy; Dendritic Cell; Tumor Antigen; T Cell; Vaccine; Adoptive Transfer

\section{Introduction}

Melanoma, a type of cancer derived from pigment-producing melanocytes of the skin, is a disease of major public health significance. Although it is less common than non-melanoma skin cancers (basal cell carcinoma and squamous cell carcinoma), melanoma is by far the most lethal form of skin cancer due to its propensity to metastasize to a number of vital organs, including the brain, lungs, liver, and other visceral organs [1]. Recent data collected by the International Agency for Research on Cancer estimate that nearly 200,000 cases of melanoma are diagnosed annually worldwide, and approximately 46,000 cancer-related deaths are attributed to melanoma each year [2]. In the United States alone, melanoma is the sixth most common fatal malignancy, accounting for approximately $4 \%$ of all cancer-related deaths [3], and studies conducted by the Surveillance, Epidemiology, and End Results (SEER) program and others have shown that melanoma incidence rates have continually increased over the previous 40 years [4-6]. Additionally, the annual direct costs for treating melanoma patients in just the United States are estimated to be over $\$ 2.8$ billion [7]. Taking into account that a recent study ranked North America only fourth in melanoma incidence worldwide [8], these statistics and economic impacts of melanoma cases become even more overwhelming and highlight the need to address treatment strategies for this global public health concern.

Although surgical removal of early-stage primary melanomas is highly successful in eradicating disease, the majority of melanoma patients are not diagnosed until later stages of metastatic disease. In these cases, surgery is oftentimes either not possible or largely ineffective as a treatment [9], and five-year survival rates for melanoma patients drop from $98.7 \%$ for those with localized disease to a staggering $15.5 \%$ for individuals with malignant melanoma [10]. Additionally, traditional systemic therapies such as chemotherapy and radiation also exhibit limited efficacy and are characterized by variable response rates, lack of durable responses, toxic side effects, and minimal impact on survival $[1,11,12]$. Therefore, alternative therapeutic approaches are necessary as treatment options for patients with metastatic melanoma. Recently, immunotherapeutic strategies have emerged as potential treatment options designed to induce or enhance anti-tumor immune responses in melanoma patients. In this review, these immunotherapies are discussed, with emphasis on both current challenges faced in eliciting/ maintaining robust anti-melanoma immunity and recent 
insights into melanoma-associated immune dysfunction and immune evasion mechanisms that suggest potential strategies for improving current and developing novel immunotherapy regimens for the treatment of melanoma.

\section{Evidence for Immunity to Melanoma and Identification of Melanoma Tumor Antigens}

The concept of anti-tumor immunity is relatively new to the field of immunology. Once largely ignored because of the idea that tolerance to self antigens $(\mathrm{Ag})$ would preclude an immune response to transformed tumor cells derived from the host's self, this field has seen an explosion of data over the past 30 years, and it is now widely accepted that 1) anti-tumor immune responses can be induced and 2) tumor cells can be eradicated by host anti-tumor immune responses. Some of the first evidence for the existence of anti-tumor immunity came from clinical studies documenting a link between melanoma and vitiligo, or autoimmune depigmentation of the skin resulting from destruction of melanocytes. That the same source of host cells (melanocytes in this case) giving rise to cancer could also be the target of autoimmune destruction suggested the potential for immune recognition of melanoma, and this hypothesis was supported by studies in the 1960s reporting regression of primary and metastatic melanomas in patients who developed vitiligo either spontaneously or following treatment $[13,14]$. Subsequent studies later documented that the development of vitiligo is a positive prognostic factor for survival of patients with early stage melanoma $[15,16]$, and similar findings have recently been reported with respect to metastatic melanoma as well [17].

To complement those studies demonstrating a link between vitiligo and enhanced survival of melanoma patients, additional support for immunity to melanoma began to emerge in the 1980s from studies reporting that tumor-specific cytotoxic T lymphocytes (CTL) could be recovered from either the blood or tumors of melanoma patients $[18,19]$. Shortly thereafter, it was shown that $\mathrm{CD}^{+} \mathrm{T}$ cell clones isolated from melanoma patients were capable of recognizing shared Ag expressed by both melanoma cells and normal melanocytes [20]. With the demonstration that self $\mathrm{Ag}$ expressed on melanoma cells could be recognized by $\mathrm{CD}^{+} \mathrm{T}$ cells, significant efforts became focused on identifying these Ag because of their ability to serve as targets of anti-tumor immune responses and because of their potential utility in the design of anti-melanoma immunotherapies.

Over the last 20 years, a number of melanoma Ag capable of being recognized by $\mathrm{T}$ cells have been identified. The first groups of these Ag to be discovered were tumor-associated Ag belonging to the cancer testis $\mathrm{Ag}$ and the melanocyte differentiation protein-derived Ag families. Cancer testis Ag are normally restricted in their expression to immune privileged adult germ-line cells but become aberrantly expressed in a number of cancer types, making them attractive targets for immunotherapies because of the limited risk of cross-reactivity against healthy host tissue. Van der Bruggen et al. cloned the first cancer testis Ag, MAGE-A1, in 1991 [21], and since that time several other cancer testis $\mathrm{Ag}$, including additional members of the MAGE family as well as BAGE/ GAGE family members and NY-ESO, have all been found to be expressed by melanomas. The identification of these tumor-associated $\mathrm{Ag}$ has recently been reviewed elsewhere [22]. At the same time, melanocyte differenttiation proteins, which are proteins involved in pigment production by normal melanocytes, were also found to be the source of several Ag also expressed on melanomas and recognized by tumor-infiltrating lymphocytes. These Ag, which include epitopes of MART-1/Melan-A, gp100, TRP-1, TRP-2, and tyrosinase, were shown to be presented in the context of a variety of HLA restriction elements [23-27] and therefore became candidate targets for melanoma immunotherapies as well. Importantly, subsequent research using both standard and preclinical murine models also identified in the murine system melanocyte differentiation protein-derived $\mathrm{Ag}$ homologous to their human counterparts [28-30], making it possible to evaluate a number of criteria important for consideration in the development of human melanoma immunotherapy clinical trials, including the mechanisms by which tumorassociated $\mathrm{Ag}$ are presented to $\mathrm{CD}^{+} \mathrm{T}$ cells [31], the impact of self-tolerance on the induction of immune responses against a shared Ag $[32,33]$, and the efficacy of immunotherapeutic strategies in eliciting host immune responses against these Ag [33-35]. Such model systems continue to be important for improving our understanding of anti-tumor immunity and for refining and optimizing melanoma immunotherapies that target these shared tumor Ag.

In addition to their expression of several shared cancer testis $\mathrm{Ag}$ and melanocyte differentiation protein-derived $\mathrm{Ag}$, a number of melanomas have also been shown to express tumor-specific Ag recognized by $\mathrm{T}$ lymphocytes. These Ag include unique epitopes resulting from mutations to CDK4 [36], $\beta$-catenin [37], and MUM-1 [38] that are recognized by $\mathrm{CD} 8^{+} \mathrm{T}$ lymphocytes, as well as tumor-specific epitopes derived from $\mathrm{CDC} 27$ [39] and LDLR/FUT [40] that are HLA class II-restricted and recognized by $\mathrm{CD}^{+} \mathrm{T}$ lymphocytes. Most recently, phosphopeptides have also been identified on melanomas as a novel class of tumor-specific Ag. Many of these $\mathrm{Ag}$ are derived from proteins that become phosphorylated during the transformation process, so while the source proteins are shared between both melanoma cells and 
healthy melanocytes, the phosphorylated epitopes are expressed uniquely or differentially by melanoma. Zarling et al. have reported the identification of such phosphopeptides expressed on multiple human melanoma cell lines, including phosphorylated epitopes derived from CDC25b, IRS2, and $\beta$-catenin [41]. Importantly, in this study it was shown using a preclinical murine model that these phosphopeptides are distinguished from their nonphosphorylated counterparts by CTL generated in response to immunization with phosphopeptide-pulsed bone marrow-derived dendritic cells (BMDC), and the CTL generated were capable of recognizing endogenously processed phosphopeptides on melanoma cell lines. Similarly, MHC class II-restricted phosphopeptides have also been found to be expressed by human melanomas, and phospho-MART-1-specific $\mathrm{CD}^{+} \mathrm{T}$ cells recovered from PBMC of a melanoma patient were able to recognize HLA-DR $1^{+}$, MART $-1^{+}$allogeneic melanoma cells derived from a number of melanoma patients [42]. Such tumor-specific Ag carry significant promise for their potential use in melanoma immunotherapies because, when compared to tumor-associated Ag shared by both melanoma cells and healthy melanocytes, their use overcomes the need to break tolerance to self $\mathrm{Ag}$ and minimizes the risk of cross-reactivity that could contribute to undesirable autoimmune disease.

\section{Current Approaches and Obstacles to Melanoma Immunotherapy}

\subsection{Peptide/Protein-Based Cancer Vaccines That Target Melanoma Ag to Host Antigen-Presenting Cells}

The identification of a large number of tumor Ag expressed by melanoma has paved the way for delivery of these $\mathrm{Ag}$ as cancer vaccines designed to evoke host antitumor immune responses. Delivery of these Ag may occur in a variety of forms, many of which rely on processing and/or presentation of Ag to host $\mathrm{T}$ lymphocytes by endogenous antigen-presenting cells (APC). Peptideand protein-based melanoma vaccines involve direct administration of synthetic melanoma Ag to the host and in their simplest form have been met with minimal success. One of the first cancer vaccine clinical trials conducted involved immunization of melanoma patients with a cancer testis Ag MAGE-3-derived peptide. In this study, only 2 of 14 patients exhibited partial tumor regression, and it is unclear whether this regression was attributable to vaccine efficacy as no MAGE-3 peptide-specific lymphocytes were detected in patients following immunization [43]. Alternatively, an early study in which melanoma patients were immunized with the immunodominant epitope derived from the melanocyte differentiation protein MART-1/Melan-A demonstrated an increa- sed frequency of peptide-specific precursors in PBMC of several immunized patients, but detection of specific cytotoxicity by these cells required multiple in vitro restimulations, and tumor regression was not observed in any patients [44]. Similarly, another group conducting a MART-1 peptide vaccine in patients with resected melanoma reported that although $\sim 50 \%$ of immunized patients exhibited an increase in Ag-specific reactivity toward this peptide as determined by IFN $\gamma$ ELISA analysis following in vitro restimulation of isolated PBMC, the number of Ag-specific CTL measured via ELISPOT assay indicated a low precursor frequency of these cells following vaccination, and there was no correlation between ELISPOT activity and relapse-free survival in these patients [45].

One possible explanation for the poor clinical outcome of these early trials is that vaccine efficacy was limited by self-tolerance to the shared tumor Ag that was used for immunization. To address this potential issue, subsequent studies were conducted utilizing modified peptide vaccines. Melanoma patients immunized with a gp100 peptide modified by a single amino acid substitution of threonine to methionine at position 2 (which also increased the peptide's binding affinity for HLA-A2) exhibited significantly greater CTL responses against both the native gp100 peptide and melanoma cells than did patients immunized with the unmodified peptide $(91 \%$ versus 25\%) [46]. Ag-specific reactivity of PBMC from patients immunized with the modified gp100 epitope was also observed without the need for any in vitro restimulation, indicating the induction of significantly higher frequencies of Ag-specific cells achieved with this modified peptide vaccine when compared to the frequency of those cells observed in the aforementioned studies involving vaccination with native peptides. However, despite the enhanced response to immunization with the modified gp100 peptide, objective cancer regression was not observed in any of these patients, and less than $25 \%$ of the patients exhibited even mixed responses with complete or partial regression of some lesions. Similar data were obtained by another group utilizing this modified gp100 peptide; while robust $\mathrm{Ag}$-specific $\mathrm{CD} 8^{+} \mathrm{T}$ cell responses were consistently elicited in vaccinated patients, objective clinical benefits remained variable $[47,48]$.

The paradoxical outcomes of these early peptide-based vaccine clinical trials that achieved enhanced levels of tumor-specific $\mathrm{CD}^{+} \mathrm{T}$ cell responses in patients yet often limited or no clinical benefit may be explained by the possiblity that tumor "evolution" in the face of a functional anti-tumor immune response resulted in the recurrence or progression of disease characterized by melanoma cells that could no longer be recognized by the Ag-specific immune effectors elicited through vaccinetion. Because $\mathrm{CD}^{+} \mathrm{T}$ cells must recognize $\mathrm{Ag}$ in the 
context of an appropriate restriction element, tumors may disguise themselves by either downregulating expression of a particular epitope or by downregulating expression of the restriction element necessary for presenting that epitope. Accordingly, loss of HLA class I expression has been reported for a variety of human tumors [49], including melanomas from patients receiving immunotherapy [50]. Furthermore, downregulation or mutation of molecules associated with Ag processing and presentation, such as the transporter associated with Ag processing (TAP), can lead to decreased expression of HLA molecules and/or lower levels of $\mathrm{Ag}$ expression on the tumor cell surface [51,52], and this phenomenon has been observed both in melanoma patients [53] and in the B16 murine melanoma model system [54]. While downregulation of HLA molecules by tumors may confer resistance to recognition by CTL, it could also make them susceptible to attack by NK cells [55]. On the other hand, maintenance of HLA expression but selective loss of Ag expression by melanoma would enable immune escape from both potential effector cells. Interestingly, anti-tumor $\mathrm{CD}^{+} \mathrm{T}$ cell responses that are effective in eliminating tumor cells may actually contribute to the process of tumor immune escape by driving the selection of Ag-loss variants, and such selection has been seen in melanoma patients immunized with synthetic MDP-derived peptides. For example, whereas tumor metastases in axillary lymph nodes expressed MART-1/Melan A prior to immunization, growing metastases at this site showed reduced Ag expression 3 months after a vaccination that elicited MART-1/Melan A-specific CTL, and total loss of this Ag's expression was observed 6 months after vaccination [56]. The evolution of tumor Ag-loss variants may therefore explain the progression or recurrence of cancer often observed in melanoma patients exhibiting robust tumor Ag-specific CTL responses [57].

To circumvent the outgrowth of tumor Ag-loss variants that may occur following vaccination with a single peptide, multipeptide immunization strategies have been employed that aim to elicit responses to several tumor Ag. Induction of CTL responses against several epitopes allows for the potential of continued immune recognition of tumor cells that may downregulate expression of a given Ag. In a study involving stage IV melanoma patients who had been vaccinated with a combination of 4 peptides derived from the melanocyte differentiation proteins gp100 and tyrosinase, $40 \%$ of patients exhibited CTL reactive to these peptides in PBL, and all patients displayed vaccine-induced CTL responses in sentinel lymph nodes. Importantly, CTL expanded from the sentinel lymph nodes of these patients were functional effectors capable of lysing melanoma cells naturally expressing tyrosinase or gp100 [58]. While these findings were initially promising, another report on vaccination of melanoma patients with these 4 peptides and a tetanus helper peptide used to elicit $\mathrm{CD}^{+} \mathrm{T}$ cell help showed that although CTL responses were observed in $80 \%$ of immunized patients, objective clinical responses were seen in only $15 \%$ of patients [59]. More promising results were observed in a follow-up study in patients with resected stage IIB-IV melanoma that combined this multipeptide vaccination with administration of IL-2, a cytokine known to support $\mathrm{T}$ cell proliferation. At the time of the report, between $40 \%-50 \%$ of vaccinated patients remained disease-free at 2 years, depending on the time of IL-2 administration [60]. Additionally, of those patients who failed to mount a $\mathrm{T}$ cell response to vaccinating peptides, only $42 \%$ remained disease-free 2 years after surgery, whereas $70 \%$ of patients who did mount vaccine-induced $\mathrm{T}$ cell responses remained free of disease during this time. It is unclear whether the difference in clinical benefits of these two trials reflects the use of IL-2 as an adjuvant or the enrollment of patients with resected melanomas in the latter trial. Regardless, while much remains to be learned about factors that regulate the induction of anti-tumor immunity by peptide-based vaccines, the benefits observed in some patients in these early trials have encouraged pursuit of optimized multipeptide vaccine regimens. In this light, multipeptide vaccination trials have since been conducted that combine 12 peptides derived from a combination of cancer testis $\mathrm{Ag}$ and melanocyte differentiation proteins. Ten of these 12 peptides were shown to be immunogenic [61] and when compared to the aforementioned 4-peptide vaccine, the 12-peptide vaccine induced greater CTL response rates and magnitude in patients with resected stage IIBIV melanoma. Disease-free survival in patients enrolled in this trial also correlated with $\mathrm{T}$ cell responses measured [62]. Similarly, another multipeptide vaccine trial has also been conducted with 6 epitopes that target $\mathrm{CD} 4^{+}$ helper $\mathrm{T}$ cells, and like those vaccines targeting $\mathrm{CD} 8^{+} \mathrm{T}$ cells, while $>80 \%$ of patients exhibited vaccine-induced helper $\mathrm{T}$ cell responses, $<25 \%$ of patients exhibited either objective clinical responses or durable stable disease [63]. Most recently, a vaccine combining these $12 \mathrm{CD}^{+} \mathrm{T}$ cell-specific peptides and $6 \mathrm{CD} 4^{+} \mathrm{T}$ cell-specific peptides was administered to melanoma patients to determine whether melanoma-associated helper peptides could augment anti-tumor CTL responses. Surprisingly, while nearly $80 \%$ of patients vaccinated with the $12 \mathrm{CD}^{+} \mathrm{T}$ cell-specific peptides displayed Ag-specific $\mathrm{T}$ cells in PBMC,$<20 \%$ of patients vaccinated with both the $\mathrm{CD}^{+}$ $\mathrm{T}$ cell-specific and $\mathrm{CD}^{+} \mathrm{T}$ cell-specific peptides exhibited $\mathrm{CD} 8^{+} \mathrm{T}$ cell responses to the vaccine [64]. A similar outcome was documented in another multipeptide vaccine trial combining modified gp100 and MART-1 HLA class I-restricted peptides with a class II-restricted gp100 peptide [65]. While it is possible that a loss of CTL re- 
covery from PBMC could reflect better homing of CTL to tumor deposits in the presence of $\mathrm{CD}^{+}$helper $\mathrm{T}$ cell responses, the former study involved resected melanoma patients who exhibited no clinically evident disease at the onset of the trial, and neither study reported any clinical benefit to the inclusion of class II-restricted peptides in the vaccine. An alternative explanation for these findings is that vaccination with a combination of peptides for both helper and cytotoxic $\mathrm{T}$ cells led to the induction of $\mathrm{CD}^{+}$regulatory $\mathrm{T}$ cells (Tregs) that dampened the magnitude of vaccine-induced $\mathrm{CD}^{+} \mathrm{T}$ cell responses. Suppression of $\mathrm{Ag}$-specific $\mathrm{CD}^{+} \mathrm{T}$ cell responses by $\mathrm{CD} 4^{+}$ CD25 ${ }^{+}$Tregs has been observed by a group studying TRP-2-specific T cell responses in the B16 murine melanoma model system [66], and others have shown that $\mathrm{CD}^{+}$Tregs suppress vaccine-induced $\mathrm{CD}^{+} \mathrm{T}$ cell responses to this tumor [67]. CD4 ${ }^{+}$Tregs have also been shown to be induced by vaccination with a full-length recombinant NY-ESO-1 protein in adjuvant. Vaccination with full-length protein requires $\mathrm{Ag}$ processing by host APC and enables presentation of multiple epitopes derived from the source protein. Although this maneuver yielded effective anti-tumor immunity in a preclinical animal study [68] and induced both $\mathrm{CD}^{+}$and $\mathrm{CD}^{+}$effector $\mathrm{T}$ cell responses in a phase I clinical trial enrolling melanoma patients with fully resected disease [69], immunization of patients with advanced melanoma resulted in significantly weaker effector responses that correlated with vaccine-induced accumulation of $\mathrm{CD} 44^{+} \mathrm{CD} 25^{+}$Fox$\mathrm{P}^{+}$Tregs in both the blood and tumor tissue [70,71]. It is possible that the differences in tumor burden in patients enrolled in these trials accounts for these discrepancies, and the heavy tumor burden in patients in the latter trial may have impacted the differentiation program of $\mathrm{CD}^{+}$ $\mathrm{T}$ cells following Ag recognition. Therefore, while these collective findings demonstrate the efficacy of multipeptide- and protein-based vaccines in some patients, they also highlight the need to better understand factors that regulate the ultimate success of these vaccines so that their clinical potential may be maximized in a broad range of melanoma patients, particularly those with advanced stage disease.

\subsection{DNA-Based Cancer Vaccines That Target Melanoma Ag to Host Antigen-Presenting Cells}

Another approach for targeting melanoma $\mathrm{Ag}$ to host $\mathrm{APC}$ is vaccination with genes encoding these tumor Ag. A variety of DNA-based vaccination strategies have been employed, including the use of both naked DNA and vector-mediated delivery of genes to APC. In an early animal study involving vaccination with naked plasmid DNA encoding foreign human gp100, Ag-specific CTL were generated that conferred protection against a sub- sequent challenge with B16 melanoma engineered to express the human homolog of this $\mathrm{Ag}$ [72]. Similar findings were observed in a B16-OVA melanoma model system following vaccination of mice with naked plasmid DNA encoding OVA; however, vaccination with plasmid DNA encoding TRP-2 did not confer protection against a subsequent challenge with wild type B16, despite the induction of a TRP-2 Ag-specific $\mathrm{CD}^{+} \mathrm{T}$ cell response [73]. These findings are consistent with those of other studies evaluating naked plasmid-based DNA vaccination against self melanocyte differentiation proteinderived Ag [74,75], suggesting that self-tolerance limits the anti-tumor efficacy of immune responses elicited by this vaccination maneuver. Naked DNA vaccines have yielded similar outcomes in human clinical trials as well. In one trial involving stage IV melanoma patients vaccinated with plasmid DNA encoding two tyrosinase peptides, tetramer staining analysis of $\mathrm{PBL}$ revealed that nearly $50 \%$ of vaccinated patients mounted Ag-specific $\mathrm{CD}^{+} \mathrm{T}$ cell responses, but these responses were transient and did not lead to tumor regression in any patients [76]. Another trial in which stage IV melanoma patients were vaccinated with plasmid DNA encoding MART-1/Melan-A epitopes resulted in induction of immunity to these $\mathrm{Ag}$ in $\sim 25 \%$ of patients, and although induction of such immunity correlated with time to disease progresssion, it did not result in any objective clinical response to tumors [77].

The observation that naked DNA vaccines are capable of eliciting in both model animals and melanoma patients $\mathrm{CD}^{+} \mathrm{T}$ cell responses that have little to no anti-tumor efficacy is similar to the aforementioned results obtained with many peptide/protein-based melanoma vaccines. One possible explanation for this paradox is that the $\mathrm{CD}^{+} \mathrm{T}$ cells induced by these vaccination strategies are not functional effectors. In this light, it is worth noting that naturally occurring anti-tumor $\mathrm{CD}^{+} \mathrm{T}$ cells recovered from both tumors [78-80] and peripheral blood [81] of melanoma patients have frequently been shown to be dysfunctional, and studies that have evaluated melanoma vaccine-induced frequency of Ag-specific T cells by both tetramer staining and functional assays have revealed a large percentage of Ag-specific T cells lacking effector function [47,82]. The basis for this anti-tumor $\mathrm{T}$ cell dysfunction has often been unclear and could reflect either a direct suppression of $\mathrm{T}$ cell effector activity by melanoma cells and/or factors within the tumor microenvironment or, alternatively, the suboptimal induction of anti-tumor $\mathrm{T}$ cell immunity by tumor-influenced APC. As the role for APC, and particularly dendritic cells (DC), in the induction of anti-tumor immune responses has become appreciated [83-85], and as critical insights into the role of DC maturation and activation status in directing $\mathrm{T}$ cell tolerance versus activation have been gained 
[86-88], it is appealing to speculate that tumors might interfere with the function of DC and their ability to induce anti-tumor $\mathrm{T}$ cell immunity. Evidence to support this hypothesis comes from recent studies utilizing a preclinical murine B16-F1 metastatic melanoma model. In these studies, $\mathrm{CD} 8^{+} \mathrm{T}$ cell responses induced against both a neoantigen (the $\mathrm{OVA}_{257}$ epitope of chicken ovalbumin) and a highly conserved melanocyte differentiation antigen derived from tyrosinase (the $\mathrm{Tyr}_{369}$ epitope) are characterized by robust proliferation but minimal effector function when naive $T$ cells are stimulated by endogenous cross-presenting APC in late-stage tumor-bearing mice [31]. This incompletely differentiated $\mathrm{CD} 8^{+} \mathrm{T}$ cell phenotype was also observed in tumor-bearing mice when exogenous protein, instead of tumor cells, was the source of $\mathrm{Ag}$ for cross-presenting APC. However, $\mathrm{CD} 8^{+}$ $\mathrm{T}$ cells differentiated into functional effectors in mice with late-stage tumors when antigen was presented either by activated, exogenous BMDC [31] or by endogenous APC following administration of exogenous IL-12 [89], a proinflammatory cytokine normally secreted by activated $\mathrm{DC}$ and involved in stimulating $\mathrm{T}$ cell effector function $[90,91]$. These findings demonstrate that $\mathrm{CD} 8^{+}$ $\mathrm{T}$ cells can differentiate into functional effectors in the context of advanced stage melanoma when stimulated appropriately and suggest that dysfunctional $\mathrm{T}$ cell responses may arise from insufficient stimulation by tumor-associated APC. Furthermore, recent studies have formally shown that B16 melanoma-derived factors suppress the maturation and activation of BMDC [92] and the DC lines DC2.4 and JAWSII [93,94]. Interestingly, one of these studies demonstrated that the extent of DC2.4 immunosuppression correlates with the tumorigenicity of the melanoma under study, with the highly aggressive B16-F1 melanoma suppressing DC maturation and activation to a significantly greater extent than the poorly tumorigenic D5.1G4 melanoma, a chemically mutated variant of B16 [93]. These data suggest that tumor/DC interactions may play a critical role in regulating the overall quality of an anti-tumor immune response and its ability to control tumor outgrowth. Suppression of DC maturation and activation by tumor-derived factors may render these cells unable to support stimulation of functional effector T cell responses. Additionally, others have described tumor-associated induction of immunoregulatory, tolerogenic DC that actively suppress anti-tumor $\mathrm{CD}^{+} \mathrm{T}$ cell activation [95-97]. It is therefore important to better understand how both tumor and vaccine site [98] microenvironmental factors influence the maturation and activation of APC and the induction of anti-tumor immune responses, and these factors must become important considerations in the design and optimization of vaccine protocols, particularly those that target endogenous APC for stimulation of anti-tumor T cell immunity.
Because of the limited efficacy of naked DNA vaccines and the realization that such therapy might not be sufficient to deliver tumor Ag to APC with immunostimulatory capacity, strategies for delivering genes encoding tumor Ag to endogenous APC in a more immunogenic setting have been explored. In this light, oral immunization of mice with a recombinant strain of attenuated S. typhimurium carrying plasmid DNA encoding gp100 and TRP-2 peptide epitopes fused to the murine ubiquitin gene (to facilitate Ag processing and presentation) broke self-tolerance to these tumor $\mathrm{Ag}$ and induced $\mathrm{Ag}$-specific $\mathrm{CD}^{+} \mathrm{T}$ cell responses that conferred protecttion against a lethal challenge with the poorly immunogenic B16G3.26 melanoma [99]. Similarly, replicasemediated DNA and RNA vaccine strategies that induce anti-viral signaling pathways, thereby triggering "danger signals" that may increase vaccine immunogenicity, have been more effective in inducing anti-tumor immunity $[100,101]$ and protection from melanoma challenge [102] than their naked nucleic acid vaccine counterparts. Protective immunity against B16 melanoma has also been achieved with a TRP-2-encoding adenovirus-based gene delivery system [103]. Additional promising data has recently emerged from a murine system employing a coronavirus-based vector encoding GM-CSF and a model tumor Ag. Delivery of this vector to DC induced their maturation and led to the induction of Ag-specific CTL as well as both prophylactic and therapeutic immunity against metastatic melanoma. This work was also extended to a preclinical model in which HLA-A2-transgenic mice were immunized with the coronavirus vector encoding an Ag derived from MART-1/Melan-A, and induction of a robust $\mathrm{Ag}$-specific $\mathrm{CD} 8^{+} \mathrm{T}$ cell response that established a central memory pool was observed [104]. Based on these successes, vector-mediated delivery of genes encoding melanoma $\mathrm{Ag}$ have been pursued in clinical settings as well. Selective transduction of human DC obtained from sentinel lymph nodes of melanoma patients with an adenovirus vector encoding a MART-1/Melan-A Ag has been reported to activate high avidity effector $\mathrm{CD} 8^{+} \mathrm{T}$ cells and decrease the frequency of $\mathrm{CD} 4^{+}$Tregs from these nodes [105]. In a previous study, however, immunization of melanoma patients with similar adenoviral vectors encoding MART-1/Melan-A or gp100 did not elicit consistent reactivity from PBMC against these Ag. It is possible that high levels of neutralizing antibodies to adenovirus detected in patient sera prior to vaccination precluded stable expression of virus-encoded tumor $\mathrm{Ag}$ for processing and presentation by endogenous APC, thus negating the potential efficacy of this particular vector-based vaccination strategy [106]. A similar outcome was reported in a later phase I vaccinetion study using recombinant modified vaccinia virus encoding tyrosinase [107]. On the other hand, recom- 
binant vaccinia virus vectors encoding multiple melanocyte differentiation protein-derived $\mathrm{Ag}$ and costimulatory molecules have elicited Ag-specific CTL responses in melanoma patients $[108,109]$, and one clinical trial utilizing this vaccine reported regression of individual metastases in $17 \%$ of patients and stable disease in $41 \%$ of patients [110]. The difference in outcomes of these studies with vaccinia virus vectors remains unclear and highlights both the potential for success of vector-based gene immunization strategies as well as the need to better understand the factors that regulate their immunogenicity and anti-tumor capacity in melanoma patients. Future studies will offer insights into strategies for optimizing the vectors, melanoma Ag and costimulatory genes, and vaccination regimens used in these gene-based immunotherapies and will hopefully lead to improved vaccineinduced anti-tumor immune responses in melanoma patients.

\subsection{Exogenous Dendritic Cell-Based Cancer Vaccines}

In contrast to the previously described peptide/proteinand gene-based cancer vaccines that rely on stimulation of immunity to melanoma $\mathrm{Ag}$ by endogenous host APC, vaccination strategies that employ exogenous DC presenting melanoma $\mathrm{Ag}$ have also been explored. Some of the early clinical trials utilizing such exogenous DC elicited weak or no $\mathrm{CD}^{+} \mathrm{T}$ cell responses and yielded poor clinical results $[59,111]$. Importantly, though, with the emergence of data regarding regulation of $\mathrm{T}$ cell immunity by DC, it is likely that these outcomes can be explained by the use of DC that had not been appropriately matured and activated prior to immunization, and it has been shown that immature DC are tolerogenic and inhibit $\mathrm{T}$ cell effector function when administered to patients [112]. On the other hand, immunotherapy with DC that have been matured and activated in vitro should enable immunization against melanoma $\mathrm{Ag}$ in the context of an immunostimulatory APC, and such vaccination strategies have the advantage of bypassing the need for processing and presentation of tumor Ag by endogenous APC whose immunogenicity may be compromised by suppressive cells or soluble factors within the tumor microenvironment. Therefore, significant efforts have been made to optimize exogenous DC-based vaccination protocols. In murine models, CD40L-mediated activation of BMDC pulsed with either peptide Ag or tumor lysate induced robust $\mathrm{CD}^{+} \mathrm{T}$ lymphocyte responses and conferred antitumor immune protection [30,35,113]. Likewise, CpG signaling via TLR 9 mediated conversion of tolerogenic splenic DC into immunogenic DC that induce Ag-specific $\mathrm{CD}^{+} \mathrm{T}$ cell activation and anti-tumor immune protection [114]. Furthermore, exogenous DC-based vaccines have been shown to be superior to alternative vacci- nation maneuvers that rely on endogenous APC for stimulation of anti-tumor T cell immunity. Multiple studies comparing the efficacy of peptide-pulsed DC immunization with that of naked DNA and peptide-based vaccines involving TRP-2 Ag showed that only peptide-pulsed DC conferred protection against a subsequent challenge with B16 melanoma [33,73], despite evidence that all three maneuvers elicited Ag-specific $\mathrm{CD}^{+} \mathrm{T}$ cell responses [73]. In addition to prophylactic efficacy, this maneuver also had a significant therapeutic effect, resulting in delayed outgrowth of tumors in $40 \%$ of mice previously challenged with B16 melanoma and complete tumor rejection in $20 \%$ of these animals [73]. Similar results have also been reported for exogenous DC genetically modified to express human gp100 by liposome-mediated transfection. Immunization with these cells elicited Agspecific $\mathrm{CD}^{+}$and $\mathrm{CD}^{+} \mathrm{T}$ cell responses and was more effective than naked DNA-based vaccines in conferring both prophylactic and therapeutic anti-tumor immunity [115]. Human DC populations have also been genetically modified with plasmid cDNAs, RNAs, and different viral vectors and evaluated for their ability to stimulate tumorreactive $\mathrm{T}$ cell responses. Transduction of these $\mathrm{DC}$ with adenovirus and retroviral vectors encoding class I- and class II-restricted epitopes of gp100 or NY-ESO-1 led to more efficient stimulation of cytotoxic and helper $\mathrm{T}$ cell lines specific for these $\mathrm{Ag}$ than did transfection with either cDNA or RNA [116]. Genetic modification of human DC to express melanoma Ag may therefore be a useful means of eliciting robust anti-tumor immunity in cancer patients as well.

The promise of the aforementioned findings in both murine and preclinical systems has driven the design of many clinical trials aiming to test the therapeutic efficacy of exogenous DC-based vaccination in melanoma patients. Impressive clinical results were observed in an early trial enrolling advanced stage IV melanoma patients exhibiting progressive disease despite prior chemotherapy. Vaccination of these patients with Mage-3A1 peptidepulsed, mature monocyte-derived DC led to induction of Ag-specific CTL responses in $>75 \%$ of patients and complete regression of individual metastases in $>50 \%$ of patients [117]. In a separate study, a large percentage of high-risk stage III melanoma patients immunized with tumor lysate- and/or peptide-pulsed DC following lymph node dissection exhibited Ag-specific $\mathrm{CD}^{+} \mathrm{T}$ cell responses. In this study, the 3-year overall survival rate of vaccinated patients versus unvaccinated controls was $68.2 \%$ versus $25.7 \%$, and the corresponding disease-free survival rates during this time period were $40.9 \%$ versus $14.5 \%$ [118]. Another early trial involving immunization with DC pulsed with either tumor lysate or a mixture of several melanoma peptide $\mathrm{Ag}$ and a non-melanoma helper Ag reported induction of Ag-specific CTL and ob- 
jective clinical responses in $>30 \%$ of patients, with regression of metastases occurring in various organs. Of the 16 patients enrolled in this trial, 2 exhibited complete tumor regression [119]. More recently, patient-specific vaccines with $\mathrm{DC}$ matured after culture with irradiated autologous tumor cells have led to durable complete tumor regression in stage IV melanoma patients as well $[120,121]$. The inclusion of melanoma helper Ag or tumor lysates/autologous tumor cells during the preparation of immunizing DC allows potential targeting of $\mathrm{CD}^{+}$helper $\mathrm{T}$ cell responses in melanoma patients. Interestingly, the results observed in the studies utilizing these approaches are in stark contrast to those documented for standard peptide/protein-based immunotherapies targeting both cytotoxic and helper $\mathrm{T}$ cells, which reported diminished CTL responses and the induction of suppressive $\mathrm{CD}^{+}$Tregs $[64,65,70,71]$. A recent study has formally demonstrated that targeting both $\mathrm{CD}^{+}$and $\mathrm{CD}^{+} \mathrm{T}$ lymphocytes with peptide-pulsed $\mathrm{DC}$ vaccination enhances tumor-specific $\mathrm{CD} 8^{+} \mathrm{T}$ cell responses and clinical outcome in melanoma patients [122], and another has reported that DC-based vaccination leads to a decrease in the frequency of Tregs in peripheral blood of melanoma patients [123]. It is likely that the different outcomes of the trials employing exogenous versus endogenous DC-based vaccination strategies can be explained by differences in the context in which Ag presentation to $\mathrm{T}$ cells occurs, and these results highlight the advantages of exogenous, immunostimulatory DC-based therapies over those that rely on endogenous APC whose stimulatory capacity may be rendered sub-optimal or even tolerogenic by tumor-derived factors and/or tumor-associated cells.

Despite the overwhelming success of exogenous DCbased vaccines in the treatment of many melanoma patients, there are still a significant number of patients who exhibit little or no response to this immunotherapy, and much remains to be learned about factors that control the immunogenicity of these vaccines. For instance, although exogenous DC can be efficiently matured and activated prior to immunization of patients, it is still possible that their stimulatory capacity might be compromised by tumor-derived factors following vaccination, and the presence and/or concentration of such factors within the tumor microenvironment are likely to be patient-specific. It is interesting that gene-silencing of STAT3 in human DC with genetically engineered adenovirus expressing STAT3 shRNA resulted in more efficient TLR-induced cytokine secretion, higher resistance to melanoma-derived factors, and more efficient induction of tumor Agspecific $\mathrm{T}$ cell responses by DC [124]. STAT3 signaling is initiated by a variety of tumor-derived factors, and such signaling has been shown to inhibit DC activation and drive the differentiation of DC into myeloid-derived su- ppressor cells (MDSC) [125-127]. It is therefore likely that interfering with this and related signaling pathways in exogenously administered DC will improve their anti- tumor efficacy in melanoma patients. Likewise, DC that are genetically engineered to interfere with immunomo- dulatory receptors expressed on endogenous immune cells, such as CTLA-4 on effector T cells and GITR on Tregs, can enhance the overall immunogenicity of these cells as well $[128,129]$. Finally, others are investigating how the efficacy of exogenous DC-based vaccination is impacted by different maturation stimuli $[130,131]$, the subsets of DC used for immunization $[132,133]$, the route of immunization with DC [134,135], and the mechanism of $\mathrm{Ag}$ delivery to $\mathrm{DC}[136,137]$. Moving forward, it will be important to further evaluate these various criteria in order to optimize the immunogenicity and anti-tumor efficacy of exogenous DC-based vaccines.

\subsection{Adoptive T Cell Transfer Therapy}

In contrast to the aforementioned vaccination-based immunotherapies that aim to elicit anti-tumor immune responses in melanoma patients, adoptive cell transfer (ACT) therapy is a maneuver that aims to augment a patient's own endogenous anti-tumor immune response in order to improve its efficacy. In this procedure, peripheral blood $\mathrm{T}$ cells or tumor-infiltrating lymphocytes (TIL) are isolated from melanoma patients, expanded under immunostimulatory conditions ex vivo, and reinfused into patients in significantly larger numbers than those that were present during the patient's natural antitumor immune response. The first extensive study of ACT in melanoma patients was reported in 1994 and involved transfer of autologous TIL and high-dose IL-2. In this study, $34 \%$ of patients receiving this immunotherapy exhibited objective clinical responses [138], demonstrating the potential of this maneuver for effective treatment of melanoma patients. Unfortunately, though, the duration of the clinical responses observed in these patients was often limited and may have been due to reinfusion of a set number of total expanded TIL, many of which could have been derived from cells infiltrating the patients' tumors that were not tumor Ag-specific. Subsequent ACT trials sought to preclude this possibility by utilizing tumor $\mathrm{Ag}$-specific $\mathrm{T}$ cell clones generated by limiting dilution from bulk PBL or TIL cultures derived from melanoma patients. One advantage to this approach for generating tumor Ag-specific T cells for ACT therapy is that clones can be selected on the basis of their avidity and tumor reactivity, both of which will be highly variable in mixed $\mathrm{T}$ cell populations that are expanded in an ex vivo setting or following induction in vivo by vaccination strategies. Additionally, adoptive transfer of $\mathrm{T}$ cell clones results in significantly higher frequencies of 
Ag-specific $\mathrm{T}$ cells in patients when compared to those frequencies typically achieved following peptide- and exogenous DC-based vaccination $[46,117,139]$. However, in ACT studies involving rapidly expanded $\mathrm{T}$ cell clones exhibiting reactivity against a gp100 peptide that had been used previously to vaccinate patients, although a small percentage of patients exhibited minor or mixed responses, no patients in these trials exhibited objective clinical responses [140,141]. Similar observations were made in a study evaluating adoptive transfer of cloned $\mathrm{T}$ cells specific for either MART-1 or gp100 peptide epitopes [139]. These results may be explained by limited survival time of adoptively transferred $\mathrm{T}$ cell clones [140], exhaustion of $\mathrm{T}$ cell clones requiring multiple stimulations to achieve the threshold number of cells needed for transfer [142], the selection of tumor $\mathrm{Ag}$ loss variants following infusion of cloned $\mathrm{T}$ cells specific for a single tumor Ag $[141,143]$, or the diversity of effector phenotypes displayed by an array of clones from a patient and selection of one with suboptimal effector function for infusion [144].

To overcome the limitations of these early ACT therapy clinical trials, significant efforts have been made to optimize protocols for generating $\mathrm{T}$ cells for adoptive transfer. One strategy that has met with improved clinical success involves the initiation of multiple independent TIL cultures from melanoma biopsies followed by screening of those cultures for antitumor activity and a single round of rapid expansion of the most tumor-reactive cultures [145]. This approach enables the generation of separate TIL cultures with different antigenic specificities that can then be administered together in large enough numbers without the need for repetitive ex vivo TCR stimulation. Impressively, in one trial, transfer of such TIL into patients with metastatic melanoma that was refractory to standard therapies resulted in objective clinical responses in 6 out of 13 patients and mixed responses in another 4 patients [146]. Importantly, this trial also involved nonmyeloablative, lymphodepleting chemotherapy prior to ACT, a maneuver that had been shown to improve the therapeutic efficacy of adoptively transferred $T$ cells in murine tumor models $[147,148]$, likely owing to its elimination of endogenous regulatory cells prior to $\mathrm{T}$ cell transfer and its alteration of homeostatic mechanisms that might otherwise limit the in vivo proliferation of adoptively transferred cells. It should also be noted that this method of generating $T$ cells from TIL cultures enables simultaneous transfer of both $\mathrm{CD} 8^{+}$ $\mathrm{T}$ cells and $\mathrm{CD}^{+} \mathrm{T}$ cells, the latter of which have been shown to contribute to the persistence of $\mathrm{CD} 8^{+} \mathrm{T}$ cells in both murine and human systems $[149,150]$. A subsequent trial employing this same strategy similarly resulted in $51 \%$ of patients exhibiting objective clinical responses, including some complete responses, with regression oc- curring in metastases in the lung, liver, brain, lymph nodes, and subcutaneous and cutaneous tissue [151]. More recent trials that have utilized this strategy for generating $\mathrm{T}$ cells for $\mathrm{ACT}$ and that compared lymphodepleting chemotherapy versus myeloablative and lymphodepleting chemoradiation prior to transfer have reported complete regression of metastatic melanoma in $>20 \%$ of patients and objective clinical responses ranging from $49 \%$ - $72 \%$ of patients $[152,153]$. Moreover, of those patients in which tumor regression was complete, $95 \%$ were reported to exhibit ongoing complete regression beyond 3 years [154]. Collectively, these data are among the most impressive seen to date for melanoma immunotherapy and demonstrate the utility of ACT therapy using ex vivo expanded $\mathrm{T}$ cells for the treatment of metastatic melanoma.

Despite the successes of many ACT therapy regimens in the treatment of metastatic melanoma, not all patients exhibit objective or even partial clinical responses to this therapy. Furthermore, not all melanoma patients mount endogenous anti-melanoma immune responses, and of those who do, not all exhibit responses of the same effector quality or of the same avidity for melanoma tumor Ag. Therefore, differences in ex vivo expanded $\mathrm{T}$ cells from patient to patient may account for differences in the efficacy of ACT therapy among patients. To address this problem, an approach that is currently being explored to improve the recognition of tumors by adoptively transferred $\mathrm{T}$ cells is the genetic engineering of these cells to express receptors with high avidity and specificity for melanoma Ag. In a murine model, retroviral transduction of $\mathrm{CD}^{+}$and $\mathrm{CD} 8^{+} \mathrm{T}$ cells with vectors encoding $\mathrm{T}$ cell receptors specific for epitopes derived from TRP-1 and gp100, respectively, led to efficient expression of $\mathrm{Ag}$ specific $\mathrm{T}$ cell receptors, and adoptive transfer of these cells into mice bearing established B16 melanoma resulted in delayed tumor outgrowth [155]. Similar observations were made when PBL retrovirally transduced to express a TCR specific for a gp100-derived epitope were transferred into B16 melanoma-bearing animals [156]. Following these murine studies, genes encoding the alpha and beta chains of a MART-1-specific TCR expressed by a TIL clone that had been used for ACT therapy in a previous patient who exhibited nearly complete regression of metastatic melanoma were cloned into a retroviral vector for transduction into PBL. Melanoma patients receiving these retrovirally transduced PBL during ACT therapy exhibited durable engraftment of TCR geneengineered cells for at least 2 months, and 2 of 15 patients exhibited objective regression of melanoma metastases and persistence of gene-engineered cells 1 year post-transfer [157]. A subsequent trial using PBL engineered to express a higher avidity MART-1-specific TCR reported objective cancer regression in $30 \%$ of patients. 
In this same trial, transfer into a separate set of patients of PBL transduced with a retroviral vector encoding a murine gp100-specific TCR generated in HLA-A2 transgenic mice also led to objective clinical responses in $19 \%$ of patients [158]. Although the objective clinical response rates observed in these trials are significantly lower than the aforementioned ACT therapy trials and are likely limited by the transfer of cells targeting a single tumor $\mathrm{Ag}$, these data offer promise for the transfer of TCR gene-modified lymphocytes as a treatment option for melanoma patients from which TIL cannot be isolated or from which TIL with low avidity for tumor Ag are recovered. The success of ACT therapies utilizing TCR gene-engineered lymphocytes is also likely to improve as the methods for gene delivery and expression are optimized. For instance, in a recent study, a $\mathrm{CD} 8^{+}$ cell-specific lentiviral vector-based system has been used to drive expression on $\mathrm{CD}^{+} \mathrm{T}$ cells of a TCR recognizing a tyrosinase epitope, and this maneuver actually resulted in enhanced $\mathrm{CD} 8^{+} \mathrm{T}$ cell effector function when compared to transduction of $\mathrm{T}$ cells with a traditional, target non-specific lentivirus [159].

In addition to conferring antigenic specificity to adoptively transferred cells by introduction of genetically engineered TCR into lymphocytes, genetic engineering is also being used to improve the overall quality of cells used for adoptive transfer. Indeed, another potential explanation for the failure of ACT therapy to mediate objective clinical regression in some patients is that transferred $\mathrm{T}$ cells, despite exhibiting high avidity for tumor $\mathrm{Ag}$ and robust effector activity, are either unable to effectively traffic to tumors or are suppressed by tumorassociated factors following their infiltration. It has been shown that clinical response to ACT therapy correlates with the number of $\mathrm{T}$ cells migrating to the tumor microenvironment [160], and maneuvers to improve T cell trafficking to melanoma are likely to augment the clinical efficacy of this therapy. In fact, human melanomas have been shown to express high levels of the monocyte/ macrophage-targeting chemokines CXCL1 and CXCL8 [161, 162], and gp100-specific TCR transgenic $T$ cells retrovirally transduced to express the CXCR2 receptor for these chemokines exhibited enhanced migration to established B16 melanoma and improved tumor control [163]. Similar results were observed in both a neuroblastoma and a malignant pleural mesothelioma model when $\mathrm{T}$ cells were engineered to express CCR2b, the receptor for the chemokine CCL2 that is secreted at high levels by these tumors $[164,165]$, further highlighting the potential for genetically engineered expression of chemokine receptors on T cells to improve ACT therapies for cancer. Alternatively, in cases where $\mathrm{T}$ cells are able to effectively traffic to melanoma tumors, it is frequently reported in both murine models and in melanoma patients that these $\mathrm{T}$ cells lack effector function and are unable to control tumor outgrowth $[79,80,166-168]$. Therefore, adoptive transfer of $\mathrm{T}$ cells that have been genetically modified either to resist immunosuppressive factors or to promote durable activation and survival has the potential to improve the efficacy of ACT therapy. For instance, a recent study has evaluated the efficacy of ACT therapy with $\mathrm{CD} 8^{+} \mathrm{T}$ cells whose $c b l b$ gene had been silenced by transfection with synthetic siRNA prior to transfer. Cblb is a negative regulator of T cell activation [169], and its deficiency in $\mathrm{T}$ cells has been shown to result in $\mathrm{T}$ cell activation without the need for costimulation [170] and to confer T cell resistance to TGF $\beta$-mediated suppression and TGF $\beta$-mediated induction of Tregs [171]. Adoptive transfer of $c b l b$ gene-silenced $\mathrm{T}$ cells into mice bearing B16 melanoma delayed tumor outgrowth and enhanced survival, and these results correlated with enhanced effector activity of $\mathrm{CD}^{+}$TIL [172]. In this same study, silencing of $c b l b$ in human $\mathrm{CD} 8^{+} \mathrm{T}$ cells also resulted in augmented effector activity, even in the absence of costimulation and the presence of $\operatorname{TGF} \beta$, suggesting the potential for this approach to improve the anti-tumor efficacy of these cells during ACT therapy of melanoma patients. Similar results have been observed following adoptive transfer of $\mathrm{T}$ cells with silenced expression of the negative regulators PD-L1 and PD-L2 [173]. In other studies, $\mathrm{T}$ cells engineered to express homeostatic cytokines [174], anti-apoptotic proteins [175], and costimulatory molecules [176] also exhibited enhanced survival, effector activity, and control of tumor outgrowth. It will be interesting to determine how such engineered $\mathrm{T}$ cells impact anti-tumor immunity in human trials, and as more is learned about factors that regulate the efficacy of $\mathrm{T}$ cell responses to tumors, similar genetic engineering approaches are likely to improve the clinical outcome of ACT therapy for melanoma patients.

\section{Conclusion}

Since the discovery of anti-tumor $\mathrm{T}$ cell responses in melanoma patients and the identification of a number of melanoma tumor $\mathrm{Ag}$ recognized by these $\mathrm{T}$ cells, the emergence of data supporting immunotherapy as a treatment strategy for melanoma patients over the last few decades has been overwhelming. Vaccination strategies that rely on endogenous APC or that employ laboratorygenerated, exogenous APC to induce tumor-specific T cell responses, and ACT therapy regimens that aim to augment naturally occurring or vaccine-induced $\mathrm{T}$ cell responses in melanoma patients, have all met with varying degrees of success for the treatment of metastatic melanoma and have encouraged pursuit of immunotherapy as a viable treatment option for this cancer. As this field moves forward, it is vital that we gain an increased understanding of both basic tumor, $\mathrm{DC}$, and $\mathrm{T}$ cell boi- 
logy and the impacts that interactions between these cells and their products have on the induction and quality of anti-tumor immune responses. Identification of tumorderived factors that alter the function of both $\mathrm{DC}$ and $\mathrm{T}$ cells and elucidation of the suppressive mechanisms mediated by tumor-associated immunoregulatory cells will be important for investigating how these molecules and cells affect the quality of vaccinating cells, the targets of these vaccines, vaccine-induced immune responses, and adoptively transferred T cells in melanoma patients. Such information will suggest novel strategies for interfering with immunosuppressive pathways that might limit the efficacy of melanoma immunotherapies, leading to more robust anti-tumor immune responses and better clinical outcome in melanoma patients. Furthermore, targeting recently identified melanoma $\mathrm{Ag}$ and novel melanoma Ag identified in the future may also improve the antitumor efficacy of many immunotherapeutic strategies, as will optimization of vaccine/ACT delivery methods and the source of cells used for these therapies. Collectively, this knowledge is sure to improve the outcomes of future melanoma immunotherapy clinical trials, and it is likely to be applicable to the immunotherapeutic treatment of other cancer types as well.

\section{REFERENCES}

[1] A. M. Leung, D. M. Hari and D. L. Morton, "Surgery for Distant Melanoma Metastasis," The Cancer Journal, Vol. 18, No. 2, 2012, pp. 176-184. doi:10.1097/PPO.0b013e31824bc981

[2] J. Ferlay, H.-R. Shin, F. Bray, D. Forman, C. Mathers and D. M. Parkin, "Estimates of Worldwide Burden of Cancer in 2008: GLOBOCAN 2008," International Journal of Cancer, Vol. 127, No. 12, 2010, pp. 2893-2917. doi:10.1002/ijc. 25516

[3] E. Losina, R. P. Walensky, A. C. Geller, F. C. Beddingfield, L. L. Wolf, B. A. Gilchrest and K. A. Freedberg, "Visual Screening for Malignant Melanoma: A Cost-Effectiveness Analysis," Archives of Dermatology, Vol. 143, No. 1, 2007, pp. 21-28. doi:10.1001/archderm.143.1.21

[4] B. K. Edwards, M. L. Brown, P. A. Wingo, H. L. Howe, E. Ward, L. A. G. Ries, D. Schrag, P. M. Jamison, A. Jemal, X. C. Wu, C. Friedman, L. Harlan, J. Warren, R. N. Anderson and L. W. Pickly, "Annual Report to the Nation on the Status of Cancer, 1975-2002, Featuring Population Based Trends in Cancer Treatment," Journal of the $\mathrm{Na}$ tional Cancer Institute, Vol. 97, No. 19, 2005, pp. 14071427. doi:10.1093/jnci/dji289

[5] A. Jemal, T. Murray, A. Ghafoor, E. Ward and M. J. Thun, "Cancer Statistics, 2003," CA: A Cancer Journal for Clinicians, Vol. 53, No. 1, 2003, pp. 5-26. doi:10.3322/canjclin.53.1.5

[6] N. Howlader, A. M. Noone, M. Krapcho, N. Neyman, R. Aminou, S. F. Altekruse, C. L. Kosary, J. Ruhl, Z. Tatalovich, H. Cho, A. Mariotto, M. P. Eisner, D. R. Lewis, H. S. Chen, E. J. Feuer and K. A. Cronin, "SEER Cancer Statistics Review, 1975-2009 (Vintage 2009 Popula- tions)," National Cancer Institute, Bethesda, 2012. http://seer.cancer.gov/csr/1975_2009_pops09/

[7] A. Jemal, R. Siegel, E. Ward, Y. Hao, J. Xu and M. J. Thun, "Cancer Statistics: 2009," A Cancer Journal for Clinicians, Vol. 59, No. 4, 2009, pp. 225-249. doi:10.3322/caac.20006

[8] A. I. Riker, T. Zea and T. Trinh, "The Epidemiology, Prevention, and Detection of Melanoma," The Ochsner Journal, Vol. 10, No. 2, 2010, pp. 56-65.

[9] F. J. Lejeune, "The Impact of Surgery on the Course of Melanoma," Recent Results in Cancer Research, Vol. 160, 2002, pp. 151-157. doi:10.1007/978-3-642-59410-6_18

[10] American Cancer Society, "Cancer Facts \& Figures2008," 2008.

[11] M. B. Atkins, J. Hsu, S. Lee, G. I. Cohen, L. E. Flaherty, J. A. Sosman, V. K. Sondak and J. M. Kirkwood, "Phase III Trial Comparing Concurrent Biochemotherapy with Cisplatin, Vinblastine, Dacarbazine, Interleukin-2, and Interferon alfa-2b with Cisplatin, Vinblastine, and Dacarbazine Alone in Patients with Metastatic Malignant Melanoma (E3695): A Trial Coordinated by the Eastern Cooperative Oncology Group," Journal of Clinical Oncology, Vol. 26, No. 35, 2008, pp. 5748-5754. doi:10.1200/JCO.2008.17.5448

[12] M. B. Atkins, J. A. Sosman, S. Agarwala, T. Logan, J. I. Clark, M. S. Ernstoff, D. Lawson, J. P. Dutcher, G. Weiss, B. Curti and K. A. Margolin, "Temozolomide, Thalidomide, and Whole Brain Radiation Therapy for Patients with Brain Metastasis from Metastatic Melanoma: A Phase II Cytokine Working Group Study," Cancer, Vol. 113, No. 8, 2008, pp. 2139-2145. doi: $10.1002 /$ cncr. 23805

[13] K. H. Burdick and W. A. Hawk, "Vitiligo in a Case of Vaccinia Virus-Treated Melanoma," Cancer, Vol. 17, No. 6, 1964, pp.708-712. doi:10.1002/1097-0142(196406)17:6<708::AID-CNCR28 20170604>3.0.CO;2-3

[14] J. L. Smith, Jr. and J. S. Stehlin, Jr., "Spontaneous Regression of Primary Malignant Melanomas with Regional Metastases," Cancer, Vol. 18, No. 11, 1965, pp. 13991415 .

doi:10.1002/1097-0142(196511)18:11<1399::AID-CNCR 2820181104>3.0.CO;2-R

[15] J. J. Nordlund, J. M. Kirkwood, B. M. Forget, G. Milton, D. M. Albert and A. B. Lerner, "Vitiligo in Patients with Metastatic Melanoma: A Good Prognostic Sign," Journal of the American Academy of Dermatology, Vol. 9, No, 5, 1983, pp. 689-696. doi:10.1016/S0190-9622(83)70182-9

[16] J. C. Bystryn, D. Rigel, R. J. Friedman and A. Kopf, "Prognostic Significance of Hypopigmentation in Malignant Melanoma," Archives of Dermatology, Vol. 123, No. 8, 1987, pp. 1053-1055. doi:10.1001/archderm.1987.01660320095019

[17] P. Quaglino, F. Marenco, S. Osella-Abate, N. Cappello, M. Ortoncelli, B. Salomone, M. T. Fierro, P. Savoia and M. G. Bernengo, "Vitiligo Is an Independent Favourable Prognostic Factor in Stage III and IV Metastatic Melanoma Patients: Results from a Single-Institution Hospital-Based Observational Cohort Study," Annals of Oncology, Vol. 21, No. 2, 2010, pp. 409-414. 
doi:10.1093/annonc/mdp325

[18] M. Hérin, C. Lemoine, P. Weynants, F. Vessière, A. van Pel, A. Knuth, R. Devos and T. Boon, "Production of Stable Cytolytic T-Cell Clones Directed against Autologous Human Melanoma," International Journal of Cancer, Vol. 39, No. 3, 1987, pp. 390-396. doi:10.1002/ijc.2910390320

[19] L. M. Muul, P. J. Spiess, E. P. Director and S. A. Rosenberg, "Identification of Specific Cytolytic Immune Responses Against Autologous Tumor in Humans Bearing Malignant Melanoma," The Journal of Immunology, Vol. 138, No. 3, 1987, pp. 989-995.

[20] A. Anichini, C. Maccalli, R. Mortarini, S. Salvi, A. Mazzocchi, P. Squarcina, M. Herlyn and G. Parmiani, "Melanoma Cells and Normal Melanocytes Share Antigens Recognized by HLA-A2-Restricted Cytotoxic T Cell Clones from Melanoma Patients," The Journal of Experimental Medicine, Vol. 177, No. 4, 1993, pp. 989-998. doi:10.1084/jem.177.4.989

[21] P. van der Bruggen, C. Traversari, P. Chomez, C. Lurquin, E. de Plaen, B. van den Eynde, A. Knuth and T. Boon, "A Gene Encoding an Antigen Recognized by Cytolytic $T$ Lymphocytes on a Human Melanoma," Science, Vol. 254, No. 5038, 1991, pp. 1643-1647. doi:10.1126/science.1840703

[22] O. L. Cabellero and Y.-T. Chen, "Cancer/Testis (CT) Antigens: Potential Targets for Immunotherapy," Cancer Science, Vol. 100, No. 11, 2009, pp. 2014-2021. doi:10.1111/j.1349-7006.2009.01303.x

[23] Y. Kawakami, S. Eliyahu, C. H. Delgado, P. F. Robbins, L. Rivoltini, S. L. Topalian, T. Miki and S. A. Rosenberg, "Cloning of the Gene Coding for a Shared Human Melanoma Antigen Recognized by Autologous T Cells Infiltrating into Tumor," Proceedings of the National Academy of Sciences of the United States of America, Vol. 91, No. 9, 1994, pp. 3515-3519. doi:10.1073/pnas.91.9.3515

[24] Y. Kawakami, S. Eliyahu, C. H. Delgado, P. F. Robbins, K. Sakaguchi, E. Appell, J. R. Yannelli, G. J. Adema, T. Miki and S. A. Rosenberg, "Identification of a Human Melanoma Antigen Recognized by Tumor-Infiltrating Lymphocytes Associated with in Vivo Tumor Rejection," Proceedings of the National Academy of Sciences of the United States of America, Vol. 91, No. 14, 1994, pp. 64586462. doi:10.1073/pnas.91.14.6458

[25] R.-F. Wang, P. F. Robbins, Y. Kawakami, X. Q. Kang and S. A. Rosenberg, "Identification of a Gene Encoding a Melanoma Tumor Antigen Recognized by HLA-A31Restricted Tumor-Infiltrating Lymphocytes," The Journal of Experimental Medicine, Vol. 181, No. 2, 1995, pp. 799-904. doi:10.1084/jem.181.2.799

[26] R.-F. Wang, E. Appell, Y. Kawakam, X. Kang and S. A. Rosenberg, "Identification of TRP-2 as a Human Tumor Antigen Recognized by Cytotoxic T Lymphocytes," The Journal of Experimental Medicine, Vol. 184, No. 6, 1996, pp. 2207-2216. doi:10.1084/jem.184.6.2207

[27] V. Brichard, A. van Pel, T. Wolfel, C. Wolfel, E. de Plaen, B. Lethe, P. Culie and T. Boon, "The Tyrosinase Gene Codes for an Antigen Recognized by Autologous Cytolytic T Lymphocytes on HLA-A2 Melanomas," The Journal of Experimental Medicine, Vol. 178, No. 2, 1993, pp. 489-495. doi:10.1084/jem.178.2.489

[28] M. B. Bloom, D. Perry-Lalley, P. F. Robbins, Y. Li, M. El-Gamil, S. A. Rosenberg and J. C. Yang, "Identification of Tyrosinase-Related Protein 2 as a Tumor Rejection Antigen for the B16 Melanoma," The Journal of Experimental Medicine, Vol. 185, No. 3, 1997, pp. 453-460. doi:10.1084/jem.185.3.453

[29] V. H. Engelhard, T. N. Bullock, T. A. Colella and D. W. Mullins, "Direct Identification of Human Tumor-Associated Peptide Ags and a Preclinical Model to Evaluate Their Use," The Cancer Journal, Vol. 6, No. 3, 2000, pp. S272-S280.

[30] D. W. Mullins, T. N. J. Bullock, T. A. Colella, V. V. Robila and V. H. Engelhard, "Immune Responses to the HLAA*0201-Restricted Epitopes of Tyrosinase and Glycoprotein 100 Enable Control of Melanoma Outgrowth in HLA-A*0201-Transgenic Mice," The Journal of Immunology, Vol. 167, No. 9, 2001, pp. 4853-4860.

[31] K. M. Hargadon, C. C. Brinkman, S. L. Sheasley-O'neill, L. A. Nichols, T. N. Bullock and V. H. Engelhard, "Incomplete Differentiation of Antigen-Specific CD8 T cells in Tumor-Draining Lymph Nodes," The Journal of Immunology, Vol. 177, No. 9, 2006, pp. 6081-6090.

[32] T. A. Colella, T. N. J. Bullock, L. B. Russel, D. W. Mullins, W. W. Overwijk, C. J. Luckey, R. A. Pierce, N. P. Restifo and V. H. Engelhard, "Self-Tolerance to the Murine Homologue of a Tyrosinase-Derived Melanoma Antigen: Implications for Tumor Immunotherapy," The Journal of Experimental Medicine, Vol. 191, No. 7, 2000, pp. 1221-1232. doi:10.1084/jem.191.7.1221

[33] M. W. J. Schreurs, A. A. O Eggert, A. J. de Boer, J. L. M. Vissers, T. van Hall, R. Offringa, C. G. Figdor and G. J. Adema, "Dendritic Cells Break Tolerance and Induce Protective Immunity against a Melanocyte Differentiation Antigen in an Autologous Melanoma Model," Cancer Research, Vol. 60, No. 24, 2000, pp. 6995-7001.

[34] R. P. M. Sutmuller, L. M. van Duivenvoorde, A. van Elsas, T. N. M. Shumacher, M. A. Wildenberg, J. P. Allison, R. E. M. Toes, R. Offringa and C. J. M. Melief, "Synergism of Cytotoxic T Lymphocyte-Associated Antigen 4 Blockade and Depletion of CD25 $5^{+}$Regulatory $\mathrm{T}$ Cells in Suppression of Autoreactive Cytotoxic T Lymphocyte Responses," The Journal of Experimental Medicine, Vol. 194, No. 6, 2001, pp. 823-832. doi:10.1084/jem.194.6.823

[35] D. W. Mullins, S. L. Sheasley, R. M. Ream, T. N. Bullock, Y. X. Fu and V. H. Engelhard, "Route of Immunization with Peptide-Pulsed Dendritic Cells Controls the Distribution of Memory and Effector T cells in Lymphoid Tissues and Determines the Pattern of Regional Tumor Control," The Journal of Experimental Medicine, Vol. 198, No. 7, 2003, pp. 1023-1034. doi:10.1084/jem.20021348

[36] T. Wolfel, M. Hauer, J. Schneider, M. Serrano, C. Wolfel, E. Klehmann-Hieb, E. de Plaen, T. Hankeln, K. H. Meyer zum Buschenfelde and D. Beach, "A p16INK4a-Insensitive CDK4 Mutant Targeted by Cytoloytic T Lymphocytes in a Human Melanoma," Science, Vol. 269, No. 5228, 1995, pp. 1281-1284. doi:10.1126/science. 7652577

[37] P. F. Robbins, M. El-Gamil, Y. F. Li, Y. Kawakami, D. 
Loftus, E. Appella and S. A. Rosenberg, "A Mutated BetaCatenin Gene Encodes a Melanoma-Specific Antigen Recognized by Tumor Infiltrating Lymphocytes," The Journal of Experimental Medicine, Vol. 183, No. 3, 1996, pp. 1185-1192. doi:10.1084/jem.183.3.1185

[38] P. G. Coulie, F. Lehmann, B. Lethe, J. Herman, C. Lurquin, M. Andrawiss and T. Boon, "A Mutated Intron Sequence Codes for an Antigenic Peptide Recognized by Cytolytic T Lymphocytes on a Human Melanoma," Proceedings of the National Academy of Sciences of the United States of America, Vol. 92, No. 17, 1995, pp. 79767980.doi:10.1073/pnas.92.17.7976

[39] R.-F. Wang, X. Wang, A. C. Atwood, S. L. Topalian and S. A. Rosenberg, "Cloning Genes Encoding MHC Class II-Restricted Antigens: Mutated CDC27 as a Tumor Antigen," Science, Vol. 284, No. 5418, 1999, pp. 1351-1354. doi:10.1126/science.284.5418.1351

[40] R.-F. Wang, X. Wang and S. A. Rosenberg, "Identification of a Novel Major Histocompatibility Complex Class II-Restricted Tumor Antigen Resulting from a Chromosomal Rearrangement Recognized by $\mathrm{CD}^{+}{ }^{+} \mathrm{T}$ Cells," The Journal of Experimental Medicine, Vol. 189, No. 10, 1999, pp. 1659-1668. doi:10.1084/jem.189.10.1659

[41] A. L. Zarling, J. M. Polefrone, A. M. Evans, L. M. Mikesh, J. Shabanowitz, S. T. Lewis, V. H. Engelhard and D. F. Hunt, "Identification of Class I MHC-Associated Phosphopeptides as Targets for Cancer Immunotherapy," Proceedings of the National Academy of Sciences of the United States of America, Vol. 103, No. 40, 2006, pp. 1488914894.doi:10.1073/pnas.0604045103

[42] F. R. Depontieu, J. Qian, A. L. Zarling, T. L. McMiller, T. M. Salay, A. Norris, A. M. English, J. Shabanowitz, V. H. Engelhard, D. F. Hunt and S. L. Topalian, "Identification of Tumor-Associated, MHC Class II-Restricted Phosphopeptides as Targets of Immunotherapy," Proceedings of the National Academy of Sciences of the United States of America, Vol. 106, No. 29, 2009, pp. 12073-12078. doi:10.1073/pnas.0903852106

[43] M. Marchand, P. Weynants, E. Rankin, F. Arienti, F. Belli, G. Parmiani, N. Cascinelli, A. Bourlond, R. Vanwijck, Y. Humblet, J.-L. Canon, C. Laurent, J.-M. Naeyaert, R. Plagne, R. Deraemaeker, A. Knuth, E. Jager, F. Brasseur, J. Herman, P. G. Couiae and T. Boon, “Tumor Regression Responses in Melanoma Patients Treated with a Peptide Encoded by Gene MAGE-3," International Journal of Cancer, Vol. 63, No. 6, 1995, pp. 883-885. doi:10.1002/ijc.2910630622

[44] J. N. Cormier, M. L. Salgaller, T. Prevette, K. C. Barracchini, L. Rivoltini, N. P. Restifo, S. A. Rosenberg and F. M. Marincola, "Enhancement of Cellular Immunity in Melanoma Patients Immunized with a Peptide from MART1/Melan A," The Cancer Journal from Scientific American," Vol. 3, No. 1, 1997, pp. 37-44.

[45] F. Wang, E. Bade, C. Kuniyoshi, L. Spears, G. Jeffery, V. Marty, S. Groshen and J. Weber, "Phase I Trial of a MART-1 Peptide Vaccine with Incomplete Freund's Adjuvant for Resected High-Risk Melanoma," Clinical Cancer Research, Vol. 5, No. 10, 1999, pp. 2756-2765.

[46] S. A. Rosenberg, J. C. Yang, D. J. Schwartzentruber, P. Hwu, F. M. Marincola, S. L. Topalian, N. P. Restifo, M.
E. Dudley, S. L. Schwarz, P. J. Spiess, J. R. Wunderlich, M. R. Parkhurst, Y. Kawakami, C. A. Seipp, J. H. Einhorn and D. E. White, "Immunologic and Therapeutic Evaluation of a Synthetic Peptide Vaccine for the Treatment of Patients with Metastatic Melanoma," Nature Medicine, Vol. 4, No. 3, 1998, pp. 321-327. doi:10.1038/nm0398-321

[47] J. W. Smith II, E. B. Walker, B. A. Fox, D. Haley, K. P. Wisner, T. Doran, B. Fisher, L. Justice, W. Wood, J. Vetto, H. Maecker, A. Dols, S. Meijer, H.-M. Hu, P. Romero, W. G. Alvord and W. J. Urba, "Adjuvant Immunization of HLA-A2-Positive Melanoma Patients With a Modified gp100 Peptide Induces Peptide-Specific CD8 ${ }^{+}$ T-Cell Responses," Journal of Clinical Oncology, Vol. 21, No. 1, 2003, pp. 1562-1573. doi:10.1200/JCO.2003.09.020

[48] E. B. Walker, D. Haley, W. Miller, K. Floyd, K. P. Wisner, N. Sanjuan, H. Maecker, P. Romero, H.-M. Hu, W. G. Alvord, J. W. Smith II, B. A. Fox and W. J. Urba, "Gp100209-2M Peptide Immunization of Human Lymphocyte Antigen-A2 ${ }^{+}$Stage 1-III Melanoma Patients Induces Significant Increase in Antigen-Specific Effector and Long-Term Memory CD8 ${ }^{+} \mathrm{T}$ Cells," Clinical Cancer Research, Vol. 10, No. 2, 2004, pp. 668-680. doi:10.1158/1078-0432.CCR-0095-03

[49] F. Garrido, F. Ruiz-Cabello, T. Cabrera, J. J. Perez-Villar, M. Lopez-Botet, M. Duggan-Keen and P. L. Stern, "Implications for Immunosurveillance of Altered HLA Class I Phenotypes in Human Tumours," Immunology Today, Vol. 18, No. 2, 1997, pp. 89-95. doi:10.1016/S0167-5699(96)10075-X

[50] N. P. Restifo, F. M. Marincola, Y. Kawakami, J. Taubenberger, J. R. Yannelli and S. A. Rosenberg, "Loss of Functional Beta2-Microglobulin in Metastatic Melanomas from Five Patients Receiving Immunotherapy," Journal of the National Cancer Institute, Vol. 88, No. 2, 1996, pp. 100-108. doi:10.1093/jnci/88.2.100

[51] F. V. Cromme, J. Airey, M.-T. Heemels, H. L. Ploegh, P. J. Keating, P. L. Stern, C. J. Meijer and J. M. Walboomers, "Loss of Transporter Protein, Encoded by the TAP1 Gene, Is Highly Correlated with Loss of HLA Expression in Cervical Carcinomas," The Journal of Experimental Medicine, Vol. 179, No. 1, 1994, pp. 335-340. doi:10.1084/jem.179.1.335

[52] B. Seliger, M. J. Maeurur and S. Ferrone, "TAP off-Tumors on," Immunology Today, Vol. 18, No. 6, 1997, pp. 292-299.

[53] B. Seliger, U. Ritz, R. Abele, M. Bock, R. Tampe, G. Sutter, I. Drexler, C. Huber and S. Ferrone, "Immune Escape of Melanoma: First Evidence of Structural Alterations in Two Distinct Components of the MHC lass I Antigen Processing Pathway," Cancer Research, Vol. 61, No. 24, 2001, pp. 8647-8650.

[54] S. Agrawal, K. Reemtsma, E. Bagiella, S. F. Oluwole and N. S. Braunstein, "Role of TAP-1 and/or TAP-2 Antigen Presentation Defects in Tumorigenicity of Mouse Melanoma," Cellular Immunology, Vol. 228, No. 2, 2004, pp. 130-137. doi:10.1016/j.cellimm.2004.04.006

[55] L. Lanier, "NK Cell Recognition," Annual Review of Immunology, Vol. 23, 2005, pp. 225-274. 
doi:10.1146/annurev.immunol.23.021704.115526

[56] E. Jager, M. Ringhoffer, J. Karbach, M. Arand, F. Oesch and A. Knuth, "Inverse Relationship of Melanocyte Differentiation Antigen Expression in Melanoma Tissues and $\mathrm{CD}^{+}$Cytotoxic-T Cell Responses: Evidence for Immunoselection of Antigen-Loss Variants in Vivo," International Journal of Cancer, Vol. 66, No. 4, 1996, pp. 470-476.

doi:10.1002/(SICI)1097-0215(19960516)66:4<470::AIDIJC10>3.0.CO;2-C

[57] S. A. Rosenberg, R. M. Sherry, K. E. Morton, W. J. Scharfman, J. C. Yang, S. L. Topalian, R. E. Royal, U. Kammula, N. P. Restifo, M. S. Hughes, D. Schwartzentruber, D. M. Berman, S. L. Schwarz, L. T. Ngo, S. A. Mavroukakis, D. E. White and S. M. Steinberg, "Tumor Progression Can Occur despite the Induction of Very High Levels of Self/Tumor Antigen-Specific $\mathrm{CD}^{+} \mathrm{T}$ Cells in Patients with Melanoma," The Journal of Immunology, Vol. 175, No. 9, 2005, pp. 6169-6176.

[58] G. V. Yamshchikov, D. L. Barnd, S. Eastham, H. Galavotti, J. W. Patterson, D. H. Deacon, D. Teates, P. Neese, W. W. Grosh, G. Petroni, V. H. Engelhard and C. L. Slingluff, Jr., "Evaluation of Peptide Vaccine Immunogenicity in Draining Lymph Nodes and Peripheral Blood of Melanoma Patients," International Journal of Cancer, Vol. 92, No. 5, 2001, pp. 703-711.

doi:10.1002/1097-0215(20010601)92:5<703::AID-IJC12 50>3.0.CO;2-5

[59] C. L. Slingluff, Jr., G. R. Petroni, G. V. Yamshchikov, D. L. Barnd, S. Eastham, H. Galavottia, J. W. Patterson, D. H. Deacon, S. Hibbitts, D. Teates, P. Y. Neese, W. W. Grosh, K. A. Chianese-Bullock, E. M. Woodson, C. J. Wiernasz, P. Merrill, J. Gibson, M. Ross and V. H. Engelhard, "Clinical and Immunologic Results of a Randomized Phase II Trial of Vaccination Using Four Melanoma Peptides Either Administered in GranulocyteMacrophage Colony-Stimulating Factor in Adjuvant or Pulsed on Dendritic Cells," Journal of Clinical Oncology, Vol. 21, No. 21, 2003, pp. 4016-4026. doi:10.1200/JCO.2003.10.005

[60] C. L. Slingluff, Jr., G. R. Petroni, G. V. Yamshchikov, S. Hibbitts, W. W. Grosh, K. A. Chianese-Bullock, E. A. Bissonette, D. L. Barnd, D. H. Deacon, J. W. Patterson, J. Parekh, P. Y. Neese, E. M. Woodson, C. J. Wiernasz and P. Merrill, "Immunologic and Clinical Outcomes of Vaccination with a Multiepitope Melanoma Peptide Vaccine Plus Low-Dose Interleukin-2 Administered Either Concurrently or on a Delayed Schedule," Journal of Clinical Oncology, Vol. 22, No. 22, 2004, pp. 4474-4485. doi:10.1200/JCO.2004.10.212

[61] K. A. Chianese-Bullock, J. Pressley, C. Garbee, S. Hibbitts, C. Murphy, G. Yamshchikov, R. R. Petroni, E. A. Bissonette, P. Y. Neese, W. W. Grosh, P. Merrill, R. Fink, E. M. H. Woodson, C. J. Wiernasz, J. W. Patterson and C. L. Slingluff, Jr., "MAGE-A1-, MAGE-A10-, and gp100Derived Peptides Are Immunogenic When Combined with Granulocyte-Macrophage Colony-Stimulating Factor and Montanide ISA-51 Adjuvant and Administered as Part of a Multipeptide Vaccine for Melanoma," The Journal of Immunology, Vol. 174, No. 5, 2005, pp. 30803086.

[62] C. L. Slingluff, Jr., G. R. Petroni, K. A. Chianese-Bullock,
M. E. Smolkin, S. Hibbitts, C. Murphy, N. Johansen, W. W. Grosh, G. V. Yamshchikov, P. Y. Neese, J. W. Patterson, R. Fink and P. K. Rehm, "Immunologic and Clinical Outcomes of a Randomized Phase II Trial of Two Multipeptide Vaccines for Melanoma in the Adjuvant Setting," Clinical Cancer Research, Vol. 13, No. 21, 2007, pp. 6386-6395.

doi:10.1158/1078-0432.CCR-07-0486

[63] C. L. Slingluff, Jr., G. R. Petroni, W. Olson, A. Czarkowski, W. W. Grosh, M. Smolkin, K. A. Chianese-Bullock, P. Y. Neese, D. H. Deacon, C. Nail, P. Merrill, R. Fink, J. W. Patterson and P. K. Rehm, "Helper T-Cell Responses and Clinical Activity of a Melanoma Vaccine with Multiple Peptides from MAGE and Melanocytic Differentiation Antigens," Journal of Clinical Oncology, Vol. 26, No. 30, 2008, pp. 4973-4980. doi:10.1200/JCO.2008.17.3161

[64] C. L. Slingluff, Jr., G. R. Petroni, K. A. Chianese-Bullock, M. E. Smolkin, M. I. Ross, N. B. Haas, M. von Mehren and W. W. Grosh, "Randomized Multicenter Trial of the Effects of Melanoma-Associated Helper Peptides and Cyclophosphamide on the Immunogenicity of a Multipeptide Melanoma Vaccine," Journal of Clinical Oncology, Vol. 29, No. 21, 2011, pp. 2924-2932. doi:10.1200/JCO.2010.33.8053

[65] G. Q. Phan, C. E. Touloukian, J. C. Yang, N. P. Restifo, R. M. Sherry, P. Hwu, S. L. Topalian, D. J. Schwart-zentruber, C. A. Seipp, L. J. Freezer, K. E. Morton, S. A. Mavroukakis, D. E. White and S. A. Rosenberg, "Immunization of Patients with Metastatic Melanoma Using Both Class I- and Class II-Restricted Peptides from Melanoma-Associated Antigens," Journal of Immunotherapy, Vol. 26, No. 4, 2003, pp. 349-356. doi:10.1097/00002371-200307000-00007

[66] R. P. Sutmuller, L. M. van Duivenvoorde, A. van Elsas, T. N. Shumacher, M. E. Wildenberg, J. P. Allison, R. E. Toes, R. Offringa and C. J. Melief, "Synergism of Cytotoxic T Lymphocyte-Associated Antigen 4 Blockade and Depletion of CD25 ${ }^{+}$Regulatory T Cells in Suppression of Autoreactive Cytotoxic T Lymphocyte Responses," The Journal of Experimental Medicine, Vol. 194, No. 6, 2001, pp. 823-832. doi:10.1084/jem.194.6.823

[67] M. D. Sharma, D.-Y. Hou, Y. Lie, P. A. Koni, R. Metz, P. Chandler, A. L. Mellor, Y. He and D. H. Munn, "Indoleamine 2,3-Dioxygenase Controls Conversion of Foxp3 ${ }^{+}$ Tregs to TH17-Like Cells in Tumor-Draining Lymph Nodes," Blood, Vol. 113, No. 24, 2009, pp. 6102-6111. doi:10.1182/blood-2008-12-195354

[68] E. Maraskovsky, S. Sjolander, D. P. Drane, M. Schnurr, T. T. Le, L. Mateo, T. Luft, K. A. Masterman, T. Y. Tai, Q. Chen, S. Green, A. Sjolander, M. J. Pearse, F. A. Lemonnier, W. Chen, J. Cebon and A. Suhrbier, "NY-ESO-1 Protein Formulated in ISCOMATRIX Adjuvant Is a Potent Anticancer Vaccine Inducing Both Humoral and $\mathrm{CD} 8^{+}$T-Cell-Mediated Immunity and Protection against NY-ESO-1 ${ }^{+}$Tumors," Clinical Cancer Research, Vol. 10, No. 8, 2004, pp. 2879-2890. doi:10.1158/1078-0432.CCR-03-0245

[69] I. D. Davis, W. Chen, H. Jackson, P. Parente, M. Shackleton, W. Hopkins, Q. Chen, N. Dimopoulos, T. Luke, R. Murphy, A. M. Scott, E. Maraskovsky, G. McArthur, D. 
MacGregor, S. Sturrock, T. Y. Tai, S. Green, A. Cuthbertson, D. Maher, L. Miloradovic, S. V. Mitchell, G. Ritter, A. A. Jungbluth, Y. T. Chen, S. Gnjatic, E. W. Hoffman, L. J. Old and J. S. Cebon, "Recombinant NYESO-1 Protein with ISCOMATRIX Adjuvant Induces Broad Integrated Antibody and $\mathrm{CD}^{+}$and $\mathrm{CD} 8^{+} \mathrm{T}$ Cell Responses in Humans," Proceedings of the National Academy of Sciences of the United States of America, Vol. 101, No. 29, 2004, pp. 10697-10702. doi: $10.1073 /$ pnas. 0403572101

[70] T. Nicholaou, L. M. Ebert, I. D. Davis, G. A. McArthur, H. Jackson, N. Dimopoulos, B. Tan, E. Maraskovsky, L. Miloradovic, W. Hopkins, L. Pan, R. Venhaus, E. W. Hoffman, W. Chen and J. Cebon, "Regulatory T-CellMediated Attenuation of T-Cell Responses to the NYESO-1 ISCOMATRIX Vaccine in Patients with Advanced Malignant Melanoma," Clinical Cancer Research, Vol. 15, No. 6, 2009, pp. 2166-2173. doi:10.1158/1078-0432.CCR-08-2484

[71] L. M. Ebert, S. E. MacRaild, D. Zanker, I. D. Davis, J. Cebon and W. Chen, "A Cancer Vaccine Induces Expansion of NY-ESO-1-Specific Regulatory $\mathrm{T}$ Cells in Patients with Advanced Melanoma," PLoS One, Vol. 7, No. 10, 2012, Article ID: e48424.

doi:10.1371/journal.pone.0048424

[72] M. W. Schreurs, A. J. de Boer, C. G. Figdor and G. J. Adema, "Genetic Vaccination against the Melanocyte Lineage-Specific Antigen gp100 Induces Cytotoxic T Lymphocyte-Mediated Tumor Protection," Cancer Research, Vol. 58, No. 12, 1998, pp. 2509-2514.

[73] M. Bellone, D. Cantarella, P. Castiglioni, M. C. Crosti, A. Ronchetti, M. Moro, M. P. Garancini, G. Casorati and P. Dellabona, "Relevance of the Tumor Antigen in the Validation of Three Vaccination Strategies for Melanoma," The Journal of Immunology, Vol. 165, No. 5, 2000, pp. 2651-2656.

[74] L. W. Weber, W. B. Browne, J. D. Wolchok, R. Srinivasan, J. Qin, Y. Moroi, R. Clynes, P. Song, J. J. Lewis, A. N. Houghton, "Tumor Immunity and Autoimmunity Induced by Immunization with Homologous DNA," The Journal of Clinical Investigation, Vol. 102, No. 6, 1998, pp. 1258-1264. doi:10.1172/JCI4004

[75] W. B. Browne, R. Srinivasan, J. D. Wolchok, W. G. Hawkins, N. E. Blachere, R. Dyall, J. J. Lewis and A. N. Houghton, "Coupling and Uncoupling of Tumor Immunity and Autoimmunity," The Journal of Experimental Medicine, Vol. 190, No. 11, 1999, pp. 1717-1722. doi:10.1084/jem.190.11.1717

[76] S. T. Tagawa, P. Lee, J. Snively, W. Boswell, S. Ounpraseuth, S. Lee, B. Hickingbottom, J. Smith, D. Johnson and J. S. Weber, "Phase I Study of Intranodal Delivery of a Plasmid DNA Vaccine for Patients with Stage IV Melanoma," Cancer, Vol. 98, No. 1, 2003, pp. 144-154. doi:10.1002/cncr.11462

[77] J. Weber, W. Boswell, J. Smith, E. Hersh, J. Snively, M. Diaz, X. Lie, M. Obrocea, Z. Qiu and A. Bot, "Phase I Trial of Intranodal Injection of a Melan-A/MART-1 DNA Plasmid Vaccine in Patients with Stage IV Melanoma," Journal of Immunotherapy, Vol. 31, No. 2, 2008, pp. 215223. doi:10.1097/CJI.0b013e3181611420
[78] A. Anichini, A. Scarito, A. Molla, G. Parmiani and R. Mortarini, "Differentiation of $\mathrm{CD}^{+} \mathrm{T}$ Cells from TumorInvaded and Tumor-Free Lymph Nodes of Melanoma Patients: Role of Common Gamma-Chain Cytokines," The Journal of Immunology, Vol. 171, No. 4, 2003, pp. 21342141.

[79] R. Mortarini, A. Piris, A. Maurichi, A. Molla, I. Bersani, A. Bono, C. Bartoli, M. Santinami, C. Lombardo, F. Ravagnani, N. Cascinelli, G. Parmiani and A. Anichini, "Lack of Terminally Differentiated Tumor-specific $\mathrm{CD} 8^{+} \mathrm{T}$ Cells at Tumor Site in Spite of Antitumor Immunity to Self-Antigens in Human Metastatic Melanoma," Cancer Research, Vol. 63, No. 10, 2003, pp. 2535-2545.

[80] A. Zippelius, P. Batard, V. Rubio-Godoy, G. Bioley, D. Lienard, F. Lejeune, D. Rimoldi, P. Guillaume, N. Meidenbauer, A. Mackensen, N. Rufer, N. Lubenow, D. Speiser, J. C. Cerottini, P. Romero and M. J. Pittet, "Effector Function of Human Tumor-Specific CD8 T Cells in Melanoma Lesions: A State of Local Functional Tolerance," Cancer Research, Vol. 64, No. 8, 2004, pp. 2865-2873. doi:10.1158/0008-5472.CAN-03-3066

[81] P. P. Lee, C. Yee, P. A. Savage, L. Fong, D. Brockstedt, J. S. Weber, D. Johnson, S. Swetter, J. Thompson, P. D. Greenberg, M. Roederer and M. M. Davis, "Characterization of Circulating T Cells Specific for Tumor-Associated Antigens in Melanoma Patients," Nature Medicine, Vol. 5, No. 6, 1999, pp. 677-685. doi:10.1038/9525

[82] M.-B. Nielsen, V. Monsurro, S. A. Migueles, E. Wang, A. Perez-Diaz, K.-H. Lee, U. Kammula, S. A. Rosenberg and F. M. Marincola, "Status of Activation of Circulating Vaccine-Elicited CD8 ${ }^{+}$T Cells," The Journal of Immunology, Vol. 165, No. 4, 2000, pp. 2287-2296.

[83] L. T. Nguyen, A. R. Elford, K. Murakami, K. M. Garza, S. P. Schoenberger, B. Odermatt, D. E. Speiser and P. S. Ohashi, "Tumor Growth Enhances Cross-Presentation Leading to Limited T Cell Activation without Tolerance," The Journal of Experimental Medicine, Vol. 195, No. 4, 2002, pp. 423-435. doi:10.1084/jem.20010032

[84] S. Lorenzi, F. Mattei, A. Sistiqu, L. Bracci, F. Spadaro, M. Sanchez, M. Spada, F. Belardelli, L. Gabriele and G. Schiavoni, "Type I IFNs Control Antigen Retention and Survival of CD $8 \alpha^{+}$Dendritic Cells after Uptake of Tumor Apoptotic Cells Leading to Cross-Priming," The Journal of Immunology, Vol. 186, No. 9, 2011, pp. 5142- 5150. doi:10.4049/jimmunol.1004163

[85] T. Cao, H. Ueno, C. Glaser, J. W. Fay, A. K. Palucka and J. Banchereau, "Both Langerhans Cells and Interstitial DC Cross-Present Melanoma Antigens and Efficiently Activate Antigen-Specific CTL," European Journal of Immunology, Vol. 37, No. 9, 2007, pp. 2657-2667. doi:10.1002/eji.200636499

[86] J. Banchereau and R. M. Steinman, "Dendritic Cells and the Control of Immunity," Nature, Vol. 392, No. 6637, 1998, pp. 245-252. doi:10.1038/32588

[87] C. A. Janeway, Jr. and R. Medzhitov, "Innate Immune Recognition," Annual Review of Immunology, Vol. 20, 2002, pp. $197-216$. doi:10.1146/annurev.immunol.20.083001.084359

[88] O. Joffre, M. A. Nolte, R. Sporr and C. Reis e Sousa, "Inflammatory Signals in Dendritic Cell Activation and 
the Induction of Adaptive Immunity," Immunological Reviews, Vol. 227, No. 1, 2009, pp. 234-247. doi:10.1111/j.1600-065X.2008.00718.x

[89] A. R. Ferguson, L. A. Nichols, A. L. Zarling, E. D. Thompson, C. C. Brinkman, K. M. Hargadon, T. N. Bullock and V. H. Engelhard, "Strategies and Challenges in Eliciting Immunity to Melanoma," Immunological Reviews, Vol. 222, No. 1, 2008, pp. 28-42. doi:10.1111/j.1600-065X.2008.00620.x

[90] A. A. Filatenkov, E. L. Jacovetty, U. B. Fischer, J. M. Curtsinger, M. F. Mescher and E. Ingulli, "CD4 T CellDependent Conditioning of Dendritic Cells to Produce IL-12 Results in CD8-Mediated Graft Rejection and Avoidance of Tolerance," The Journal of Immunology, Vol. 174, No. 11, 2006, pp. 6909-6917.

[91] C. S. Schmidt and M. F. Mescher, "Peptide Antigen Priming of Naïve, But Not Memory, CD8 T Cells Requires a Third Signal That Can Be Provided by IL-12," The Journal of Immunology, Vol. 168, No. 11, 2002, pp. 5521-5529.

[92] A. Alshamsan, S. Hamdy, S. Das, A. Lavasanifar, J. Samuel and A. El-Kadi, "Validation of Bone Marrow Derived Dendritic Cells as an Appropriate Model to Study Tumor-Mediated Suppression of DC Maturation through STAT3 Hyperactivation," Journal of Pharmacy and Pharmaceutical Sciences, Vol. 13, No. 1, 2010, pp. 21-26.

[93] K. M. Hargadon, O. A. Forrest and P. R. Reddy, "Suppression of the Maturation and Activation of the Dendritic Cell Line DC2.4 by Melanoma-Derived Factors," Cellular Immunology, Vol. 272, No. 2, 2012, pp. 275-282. doi:10.1016/j.cellimm.2011.10.003

[94] K. M. Hargadon, Y. T. Ararso, O. A. Forrest and C. M. Harte, "Melanoma-Associated Suppression of the Dendritic Cell Lines DC2.4 and JAWSII," American Journal of Immunology, Vol. 8, No. 4, 2012, pp. 179-190.

[95] D. H. Munn, M. D. Sharma, D. Hou, B. Baban, J. R. Lee, S. J. Antonia, J. L. Messina, P. Chandler, P. A. Koni and A. L. Mellor, "Expression of Indoleamine 2,3-Dioxygenase by Plasmacytoid Dendritic Cells in Tumor-Draining Lymph Nodes," The Journal of Clinical Investigation, Vol. 114, No. 2, 2004, pp. 280-290.

[96] M. D. Sharma, D. Y. Hou, Y. Liu, P. A. Koni, R. Metz, P. Chandler, A. L. Mellor, Y. He and D. H. Munn, "Indoleamine 2,3-Dioxygenase Controls Conversion of Foxp3 $3^{+}$ Tregs to TH17-Like Cells in Tumor-Draining Lymph Nodes," Blood, Vol. 113, No. 24, 2009, pp. 6102-6111. doi:10.1182/blood-2008-12-195354

[97] S. K. Watkins, Z. Zhu, E. Riboldi, K. A. Shafer-Weaver, K. E. Stagliano, M. M. Sklavos, S. Ambs, H. Yagita and A. A. Hurwitz, "FOXO3 Programs Tumor-Associated DCs to Become Tolerogenic in Human and Murine Prostate Cancer," The Journal of Clinical Investigation, Vol. 121, No. 4, 2011, pp. 1361-1372. doi:10.1172/JCI44325

[98] R. C. Harris, K. A. Chianese-Bullock, G. R. Petroni, J. T. Schaefer, L. B. Brill II, K. R. Molhoek, D. H. Deacon, J. W. Patterson and C. L. Slingluff, Jr., "The Vaccine-Site Microenvironment Induced by Injection of Incomplete Freund's Adjuvant, with or without Melanoma Peptides," Journal of Immunotherapy, Vol. 35, No. 1, 2012, pp. 78-

\section{8. doi:10.1097/CJI.0b013e31823731a4}

[99] R. Xiang, H. N. Lode, T.-H. Chao, J. M. Ruehlmann, C. S. Dolman, F. Rodriguez, J. L. Whitton, W. W. Overwijk, N. P. Restifo and R. R. Reisfeld, "An Autologous Oral DNA Vaccine Protects Against Murine Melanoma," Proceedings of the National Academy of Sciences of the United States of America, Vol. 97, No. 10, 2000, pp. 5492-5497. doi:10.1073/pnas.090097697

[100]H. Ying, T. Z. Zaks, R. F. Wang, K. R. Irvine, U. S. Kammula, F. M. Marincola, W. W. Leitner and N. P. Restifo, "Cancer Therapy Using a Self-Replicating RNA Vaccine," Nature Medicine, Vol. 5, No. 7, 1999, pp. 823827. doi: $10.1038 / 10548$

[101] W. W. Leitner, H. Ying, D. A. Driver, T. W. Dubensky and N. P. Restifo, "Enhancement of Tumor-Specific Immune Response with Plasmid DNA Replicon Vectors," Cancer Research, Vol. 60, No. 1, 2000, pp. 51-55.

[102] W. W. Leitner, L. N. Hwang, M. J. de Veer, A. Zhou, R. H. Silverman, B. R. Williams, T. W. Dubensky, H. Ying and N. P. Restifo, "Alphavirus-Based DNA Vaccine Breaks Immunologic Tolerance by Activating Innate Antiviral Pathways," Nature Medicine, Vol. 9, No. 1, 2003, pp. 33-39. doi:10.1038/nm813

[103] B. N. Hangalapura, D. Oosterhoff, T. Gupta, J. de Groot, P. G. Wijnands, V. W. van Beusechem, J. den Haan, T. Tuting, A. J. van den Eertwegh, D. T. Curiel, R. J. Scheper and T. D. de Gruijl, "Delivery Route, MyD88 Signaling and Cross-Priming Events Determine the Anti-Tumor Efficacy of an Adenovirus Based Melanoma Vaccine," Vaccine, Vol. 29, No. 12, 2011, pp. 2313-2321. doi:10.1016/j.vaccine.2011.01.022

[104] L. Cervantes-Barragan, R. Zust, R. Maier, S. Sierro, J. Janda, F. Levy, D. Speiser, P. Romero, P.-S. Rohrlich, B. Ludewig and V. Thiel, "Dendritic Cell-Specific Antigen Delivery by Coronavirus Vaccine Vectors Induces LongLasting Protective Antiviral and Antitumor Immunity," mBio, Vol. 1, No. 4, 2010, Article ID: e0171-10.

[105] B. N. Hangalapura, D. Oosterhoff, S. Aggarwal, P. G. Wijnands, R. van de Ven, S. J. Santegoets, M. P. van den Tol, E. Hoojiberg, A. Pereboev, A. J. van den Eertwegh, D. T. Curiel, R. J. Scheper and T. D. de Gruijl, "Selective Transduction of Dendritic Cells in Human Lymph Nodes and Superior Induction of High-Avidity Melanoma-Reactive Cytotoxic T Cells by a CD40-Targeted Adenovirus," Journal of Immunotherapy, Vol. 33, No. 7, 2010, pp. 706-715. doi:10.1097/CJI.0b013e3181eccbd4

[106] S. A. Rosenberg, Y. Zhai, J. C. Yang, D. J. Schwartzentruber, P. Hwu, F. M. Marincola, S. L. Topalian, N. P. Restifo, C. A. Seipp, J. H. Einhorn, B. Roberts and D. E. White, "Immunizing Patients with Metastatic Melanoma Using Recombinant Adenoviruses Encoding MART-1 or gp100 Melanoma Antigens," Journal of the National Cancer Institute, Vol. 90, No. 24, 1998, pp. 1894-1900.

[107] R. G. Meyer, C. M. Britten, U. Siepmann, B. Petzold, T. A. Sagban, H. A. Lehr, B. Weigle, M. Schmitz, L. Mateo, B. Schmidt, H. Bernhard, T. Jakob, R. Hein, G. Schuler, B. Schuler-Turner, S. N. Wagner, I. Drexler, G. Sutter, N. Arndtz, P. Chaplin, J. Metz, A. Enk, C. Huber and T. Wolfel, "A Phase I Vaccination Study with Tyrosinase in Patients with Stage II Melanoma Using Recombinant Modified Vaccinia Virus Ankara (MVA-hTyr)," Cancer 
Immunology, Immunotherapy, Vol. 54, No. 5, 2005, pp. 453-467. doi:10.1007/s00262-004-0616-7

[108] D. Oertli, W. R. Marti, P. Zajac, C. Noppen, T. Kocher, E. Padovan, M. Adamina, R. Schumacher, F. Harder, M. Heberer and G. C. Spagnoli, "Rapid Induction of Specific Cytotoxic T Lymphocytes against Melanoma-Associated Antigens by a Recombinant Vaccinia Virus Vector Expressing Multiple Immunodominant Epitopes and Costimulatory Molecules in Vivo," Human Gene Therapy, Vol. 13, No. 4, 2002, pp. 569-575. doi:10.1089/10430340252809856

[109] M. Adamina, R. Rosenthal, W. P. Weber, D. M. Frey, C. T. Viehl, M. Bolli, R. W. Huegli, A. L. Jacob, M. Heberer, D. Oertli, W. Marti, G. C. Spagnoli and P. Zajac, "Intranodal Immunization with a Vaccinia Virus Encoding Multiple Antigenic Epitopes and Costimulatory Molecules in Metastatic Melanoma," Molecular Therapy, Vol. 18, No. 3, 2010, pp. 651-659. doi:10.1038/mt.2009.275

[110] P. Zajac, D. Oertli, W. Marti, M. Adamina, M. Bolli, U. Guller, C. Noppen, E. Padovan, E. Schultz-Thater, M. Heberer and G. Spagnoli, "Phase I/II Clinical Trial of a Nonreplicative Vaccinia Virus Expressing Multiple HLA-A0201-Restricted Tumor-Associated Epitopes and Costimulatory Molecules in Metastatic Melanoma Patients," Human Gene Therapy, Vol. 14, No. 16, 2003, pp. 1497-1510. doi:10.1089/104303403322495016

[111] M. C. Panelli, J. Wunderlich, J. Jeffries, E. Wang, A. Mixon, S. A. Rosenberg and F. M. Marincola, "Phase 1 Study in Patients with Metastatic Melanoma of Immunization with Dendritic Cells Presenting Epitopes Derived from the Melanoma-Associated Antigens MART-1 and gp100," Journal of Immunotherapy, Vol. 23, No. 4, 2000, pp. 487-498. doi:10.1097/00002371-200007000-00013

[112] M. V. Dhodapkar, R. M. Steinman, J. Kravovsky, C. Munz and N. Bhardwaj, "Antigen-Specific Inhibition of Effector T Cell Function in Humans after Injection of Immature Dendritic Cells," The Journal of Experimental Medicine, Vol. 193, No. 2, 2001, pp. 233-238. doi:10.1084/jem.193.2.233

[113] L. A. Lambert, G. R. Gibson, M. Maloney, B. Durell, R. J. Noelle and R. J. Barth, Jr., "Intranodal Immunization with Tumor Lysate-Pulsed Dendritic Cells Enhances Protective Antitumor Immunity," Cancer Research, Vol. 61, No. 2, 2001, pp. 641-646.

[114] X. Zhang, M. A. Munegowda, J. Yuan, Y. Wei and J. Xiang, "Optimal TLR9 Signal Converts Tolerogenic CD48-DCs into Immunogenic Ones Capable of Stimulating Antitumor Immunity via Activating CD4 ${ }^{+}$Th1/Th17 and NK Cell Responses," Journal of Leukocyte Biology, Vol. 88, No. 2, 2010, pp. 393-403. doi:10.1189/jlb.0909633

[115] S. Yang, C. E. Vervaert, J. Burch, Jr., J. Grichnik, H. F. Siegler and T. L. Darrow, "Murine Dendritic Cells Transfected with Human gp100 Elicit Both Antigen-Specific $\mathrm{CD}^{+}$and $\mathrm{CD}^{+} \mathrm{T}$-Cell Responses and Are More Effective than DNA Vaccines at Generating Anti-Tumor Immunity," International Journal of Cancer, Vol. 83, No. 4, 1999, pp. 532-540. doi:10.1002/(SICI)1097-0215(19991112)83:4<532::AID-

\section{IJC16>3.0.CO;2-K}

[116] M. Lotem, Y. Zhao, J. Riley, P. Hwu, R. A. Morgan, S. A. Rosenberg and M. R. Parkhurst, "Presentation of Tumor Antigens by Dendritic Cells Genetically Modified with Viral and Nonviral Vectors," Journal of Immunotherapy, Vol. 29, No. 6, 2006, pp. 616-627. doi:10.1097/01.cji.0000211312.36363.56

[117] B. Thurner, I. Haendle, C. Roder, D. Dieckmann, P. Keikavoussi, H. Jonuleit, A. Bender, C. Maczek, D. Schreiner, P. von den Driesch, E. B. Brocker, R. M. Steinman, A. Enk, E. Kampgen and G. Schuler, "Vaccination with Mage-3A1 Peptide-pulsed Mature, Monocyte-Derived Dendritic Cells Expands Specific Cytotoxic $\mathrm{T}$ Cells and Induces Regression of Some Metastases in Advanced Stage 4 Melanoma," The Journal of Experimental Medicine, Vol. 190, No. 11, 1999, pp. 1669-1678. doi:10.1084/jem.190.11.1669

[118] S. Markowicz, Z. I. Nowecki, P. Rutkowski, A. W. Lipkowski, M. Biernacka, A. Jakubowska-Mucka, T. Switaj, A. Misicka, H. Skurzak, H. Polowniak-Pracka and J. Walewski, "Adjuvant Vaccination with Melanoma Antigen-Pulsed Dendritic Cells in Stage III Melanoma Patients," Medical Oncology, Vol. 29, No. 4, 2012, pp. 2966-2977. doi:10.1007/s12032-012-0168-1

[119] F. O. Nestle, S. Alijagic, M. Gillier, Y. Sun, S. Grabbe, R. Dummer, G. Burg and D. Schadendorf, "Vaccination of Melanoma Patients with Peptide- or Tumor Lysate-Pulsed Dendritic Cells," Nature Medicine, Vol. 4, No. 3, 1998, pp. 323-332. doi:10.1038/nm0398-328

[120] M. G. O’Rourke, M. Johnson, C. Lanagan, J. See, J. Yang, J. R. Bell, G. J. Slater, B. M. Kerr, B. Crowe, D. M. Purdie, S. L. Elliott, K. A. Ellem and C. W. Schmidt, "Durable Complete Clinical Responses in a Phase I/II Trial Using an Autologous Melanoma Cell/Dendritic Cell Vaccine," Cancer Immunology, Immunotherapy, Vol. 52, No. 6, 2003, pp. 387-395.

[121] R. O. Dillman, A. A. Nanci, S. T. Williams, R. B. Kim, R. L. Hafer, C. L. Coleman, P. C. Wang, C. M. Duma, P. V. Chen, S. R. Selvan, A. N. Cornforth and C. DePriest, "Durable Complete Response of Refractory, Progressing Metastatic Melanoma after Treatment with a Patient-Specific Vaccine," Cancer Biotherapy \& Radiopharmaceuticals, Vol. 25, No. 5, 2010, pp. 553-557. doi:10.1089/cbr.2010.0819

[122] E. H. Aarntzen, I. J. de Vries, W. J. Lesterhuis, D. Schuurhuis, J. F. Jacobs, K. Bol, G. Schreibelt, R. Mus, J. H. de Wilt, J. B. Haanen, J. D. Schadendorf, A. Croockewit, W. A. Blokx, M. M. van Rossum, W. W. Kwok, G. J. Adema, C. J. Punt and C. G. Figdor, "Targeting CD4 $4^{+}$ T-Helper Cells Improves the Induction of Antitumor Responses in Dendritic Cell-Based Vaccination," Cancer Research, Vol. 73, No. 1, 2013, pp. 19-29. doi:10.1158/0008-5472.CAN-12-1127

[123] A. Correll, A. Tuettenberg, C. Becker and H. Jonuleit, "Increased Regulatory T-Cell Frequencies in Patients with Advanced Melanoma Correlate with a Generally Impaired T-Cell Responsiveness and Are Restored after Dendritic Cell-Based Vaccination," Experimental Dermatology, Vol. 19, No. 8, 2010, pp. e213-e221. doi:10.1111/j.1600-0625.2009.01055.x 
[124] T. Iwata-Kajihara, H. Sumimoto, N. Kawamura, R. Ueda, T. Takahashi, H. Mizuguchi, M. Miyagishi, K. Takeda and Y. Kawakami, "Enhanced Cancer Immunotherapy Using STAT3-Depleted Dendritic Cells with High Th1Inducing Ability and Resistance to Cancer Cell-Derived Inhibitory Factors," The Journal of Immunology, Vol. 187, No. 1, 2011, pp. 27-36. doi:10.4049/jimmunol.1002067

[125] Y. Nefedova, M. Huang, S. Kusmartsev, R. Bhattacharya, P. Cheng, R. Salup, R. Jove and D. Gabrilovich, "Hyperactivation of STAT3 Is Involved in Abnormal Differentiation of Dendritic Cells in Cancer," The Journal of Immunology, Vol. 172, No. 1, 2004, pp. 464-474.

[126] D. I. Gabrilovich, H. L. Chen, K. R. Girgis, H. T. Cunningham, G. M. Meny, S. Nadaf, D. Kavanaugh and D. P. Carbone, "Production of Vascular Endothelial Growth Factor by Human Tumors Inhibits the Functional Maturation of Dendritic Cells," Nature Medicine, Vol. 2, No. 10, 1996, pp. 1096-1103. doi:10.1038/nm1096-1096

[127] V. Bronte, D. B. Chappell, E. Apolloni, A. Cabrelle, M. Wang, P. Hwu and N. P. Restifo, "Unopposed Production of Granulocyte-Macrophage Colony-Stimulating Factor by Tumors Inhibits $\mathrm{CD}^{+} \mathrm{T}$ Cell Responses by Dysregulating Antigen-Presenting Cell Maturation," The Journal of Immunology, Vol. 162, No. 10, 1999, pp. 5728-5737.

[128] D. Boczkowski, J. Lee and S. Nair, "Dendritic Cells Engineered to Secrete Anti-GITR Antibodies Are Effective Adjuvants to Dendritic Cell-Based Immunotherapy," Cancer Gene Therapy, Vol. 16, No. 12, 2009, pp. 900911. doi:10.1038/cgt.2009.39

[129] S. K. Pruitt, D. Boczkowski, N. de Rosa, N. R. Haley, M. A. Morse, D. S. Tyler, J. Dannull and S. Nair, "Enhancement of Anti-Tumor Immunity through Local Modulation of CTLA-4 and GITR by Dendritic Cells," European Journal of Immunology, Vol. 41, No. 12, 2011, pp. 3553-3563. doi:10.1002/eji.201141383

[130] T. H. Han, P. Jin, J. Ren, S. Slezak, F. M. Marincola and D. F. Stroncek, "Evaluation of 3 Clinical Dendritic Cell Maturation Protocols Containing Lipopolysaccharide and Interferon-Gamma," Journal of Immunotherapy, Vol. 32, No. 4, 2009, pp. 399-407.

doi:10.1097/CJI.0b013e31819e1773

[131] R. Aguilera, C. Saffie, A. Tittarelli, F. E. Gonzalez, M. Ramirez, D. Reyes, C. Pereda, D. Hevia, T. Garcia, L. Salazar, A. Ferreira, M. Hermoso, A. Mendoza-Naranjo, C. Ferrada, P. Garrido, M. N. Lopez and F. Salazar-Onfray, "Heat-Shock Induction of Tumor-Derived Danger Signals Mediates Rapid Monocyte Differentiation into Clinically Effective Dendritic Cells," Clinical Cancer Research, Vol. 17, No. 8, 2011, pp. 2474-2483. doi:10.1158/1078-0432.CCR-10-2384

[132] H. Jonuleit, A. Giesecke-Tuettenberg, T. Tuting, B. Thurner-Schuler, T. B. Stuge, L. Paragnik, A. Kandemir, P. P. Lee, G. Schuler, J. Knop and A. H. Enk, "A Comparison of Two Types of Dendritic Cell as Adjuvants for the Induction of Melanoma-Specific T-Cell Responses in Humans Following Intranodal Injection," International Journal of Cancer, Vol. 93, No. 2, 2001, pp. 243-251. doi:10.1002/ijc. 1323

[133] E. Romano, M. Rossi, G. Ratzinger, M. A. de Cos, D. J. Chung, K. S. Panageas, J. D. Wolchok, A. N. Houghton,
P. B. Chapman, G. Heller, J. Yuan and J. W. Young, "Peptide-Loaded Langerhans Cells, Despite Increased IL15 Secretion and T-Cell Activation in Vitro, Elicit Antitumor T-Cell Responses Comparable to Peptide-Loaded Monocyte-Derived Dendritic Cells in Vivo," Clinical Cancer Research, Vol. 17, No. 7, 2011, pp. 1984-1997. doi:10.1158/1078-0432.CCR-10-3421

[134] T. Lesimple, E. M. Neidhard, V. Vignard, C. Lefeuvre, H. Adamski, N. Labarriere, A. Carsin, D. Monnier, B. Collet, G. Clapisson, B. Birebent, I. Philip, L. Toujas, M. Chokri and V. Quillien, "Immunologic and Clinical Effects of Injecting Mature Peptide-Loaded Dendritic Cells by Intralymphatic and Intranodal Routes in Metastatic Melanoma Patients," Clinical Cancer Research, Vol. 12, No. 24, 2006, pp. 7380-7388. doi:10.1158/1078-0432.CCR-06-1879

[135] W. J. Lesterhuis, I. J. de Vries, G. Schreibelt, A. J. Lambeck, E. H. Aarntzen, J. F. Jacobs, N. M. Scharenborg, M. W. van de Rakt, A. J. de Boer, S. Croockewit, M. M. van Rossum, R. Mus, W. J. Oyen, O. C. Boerman, S. Lucas, G. J. Adema, C. J. Punt and C. G. Figdor, "Route of Administration Modulates the Induction of Dendritic Cell Vaccine-Induced Antigen-Specific T Cells in Advanced Melanoma Patients," Clinical Cancer Research, Vol. 17, No. 17, 2011, pp. 5725-5735. doi:10.1158/1078-0432.CCR-11-1261

[136] L. H. Butterfield, B. Comin-Anduix, L. Vujanovic, Y. Lee, V. B. Dissette, J. Q. Yang, H. T. Vu, E. Seja, D. K. Oseguera, D. M. Potter, J. A. Glaspy, J. S. Economou and A. Ribas, "Adenovirus MART-1-Engineered Autologous Dendritic Cell Vaccine for Metastatic Melanoma," Journal of Immunotherapy, Vol. 31, No. 3, 2008, pp. 294-309. doi:10.1097/CJI.0b013e31816a8910

[137] J. C. Steele, A. Rao, J. R. Marsden, C. J. Armstrong, S. Berhane, L. J. Billingham, N. Graham, C. Roberts, G. Ryan, H. Uppal, C. Walker, L. S. Young and N. M. Steven, "Phase I/II Trial of a Dendritic Cell Vaccine Transfected with DNA Encoding Melan A and gp100 for Patients with Metastatic Melanoma," Gene Therapy, Vol. 18, No. 6, 2011, pp. 584-593. doi:10.1038/gt.2011.1

[138] S. A. Rosenberg, J. R. Yannelli, J. C. Yang, S. L. Topalian, D. J. Schwartzentruber, J. S. Weber, D. R. Parkinson, C. A. Seipp, J. H. Einhorn and D. E. White, "Treatment of Patients with Metastatic Melanoma with Autologous Tumor-Infiltrating Lymphocytes and Interleukin 2," Journal of the National Cancer Institute, Vol. 86, No. 15, 1994, pp. 1159-1166. doi:10.1093/jnci/86.15.1159

[139] C. Yee, J. A. Thompson, D. Byrd, S. R. Riddell, P. Roche, E. Celis and P. D. Greenberg, "Adoptive T Cell Therapy Using Antigen-Specific CD8 ${ }^{+} \mathrm{T}$ Cell Clones for the Treatment of Patients with Metastatic Melanoma: In Vivo Persistence, Migration, and Antitumor Effect of Transferred T Cells," Proceedings of the National Academy of Sciences of the United States of America, Vol. 99, No. 25, 2002, pp. 16168-16173. doi:10.1073/pnas.242600099

[140] M. E. Dudley, J. Wunderlich, M. I. Nishimura, D. Yu, J. C. Yang, S. L. Topalian, D. J. Schwartzentruber, P. Hwu, F. M. Marincola, R. Sherry, S. F. Leitman and S. A. Rosenberg, "Adoptive Transfer of Cloned Melanoma-Reactive T Lymphocytes for the Treatment of Patients with Metastatic Melanoma," Journal of Immunotherapy, Vol. 
24, No. 4, 2001, pp. 363-373. doi:10.1097/00002371-200107000-00012

[141] M. E. Dudley, J. R. Wunderlich, J. C. Yang, P. Hwu, D. J. Schwartzentruber, S. L. Topalian, R. M. Sherry, F. M. Marincola, S. F. Leitman, C. A. Seipp, L. Rogers-Freezer, K. E. Morton, A. Nahvi, S. A. Mavroukakis, D. E. White and S. A. Rosenberg, "A Phase I Study of Nonmyeloablative Chemotherapy and Adoptive Transfer of Autologous Tumor Antigen-Specific T Lymphocytes in Patients With Metastatic Melanoma," Journal of Immunotherapy, Vol. 25, No. 3, 2002, pp. 243-251. doi:10.1097/00002371-200205000-00007

[142] E. J. Wherry, J. N. Blattman, K. Murali-Krishna, R. van der Most and R. Ahmed, "Viral Persistence Alters CD8 T-Cell Immunodominance and Tissue Distribution and Results in Distinct Stages of Functional Impairment," Journal of Virology, Vol. 77, No. 8, 2003, pp. 4911-4927. doi:10.1128/JVI.77.8.4911-4927.2003

[143] A. Mackensen, N. Meidenbauer, S. Vogl, M. Laumer, J. Berger and R. Andreesen, "Phase I Study of Adoptive TCell Therapy Using Antigen-Specific $\mathrm{CD}^{+} \mathrm{T}$ Cells for the Treatment of Patients with Metastatic Melanoma," Journal of Clinical Oncology, Vol. 24, No. 31, 2006, pp. 5060-5069. doi:10.1200/JCO.2006.07.1100

[144] M. E. Dudley, L. T. Ngo, J. Westwood, J. R. Wunderlich and S. A. Rosenberg, "T-Cell Clones from Melanoma Patients Immunized against an Anchor-Modified gp100 Peptide Display Discordant Effector Phenotypes," Cancer Journal, Vol. 6, No. 2, 2000, pp. 69-77.

[145] M. E. Dudley, J. R. Wunderlich, T. E. Shelton, J. Even and S. A. Rosenberg, "Generation of Tumor-Infiltrating Lymphocyte Cultures for Use in Adoptive Transfer Therapy for Melanoma Patients," Journal of Immunotherapy, Vol. 26, No. 4, 2003, pp. 332-342. doi:10.1097/00002371-200307000-00005

[146] M. E. Dudley, J. R. Wunderlich, P. F. Robbins, J. C. Yang, P. Hwu, D. J. Schwartzentruber, S. L. Topalian, R. Sherry, N. P. Restifo, A. M. Hubicki, M. R. Robinson, M. Raffeld, P. Duray, C. A. Seipp, L. Rogers-Freezer, K. E. Morton, S. A. Mavroukakis, D. E. White and S. A. Rosenberg, "Cancer Regression and Autoimmunity in Patients after Clonal Repopulation with Antitumor Lymphocytes," Science, Vol. 298, No. 5594, 2002, pp. 850854. doi:10.1126/science. 1076514

[147] R. J. North, "Cyclophosphamide-Facilitated Adoptive Immunotherapy of an Established Tumor Depends on Elimination of Tumor-Induced Suppressor T Cells," The Journal of Experimental Medicine, Vol. 155, No. 4, 1982, pp. 1063-1074. doi:10.1084/jem.155.4.1063

[148] S. A. Rosenberg, P. Spiess and R. Lafreniere, "A New Approach to the Adoptive Immunotherapy of Cancer with Tumor-Infiltrating Lymphocytes," Science, Vol. 233, No. 4770, 1986, pp. 1318-1321. doi:10.1126/science.3489291

[149] E. A. Walter, P. D. Greenberg, M. J. Gilbert, R. J. Finch, K. S. Watanabe, E. D. Thomas and S. R. Riddell, "Reconstitution of Cellular Immunity against Cytomegalovirus in Recipients of Allogeneic Bone Marrow by Transfer of T-Cell Clones from the Donor," The New England Journal of Medicine, Vol. 333, No. 16, 1995, pp. 10381044. doi:10.1056/NEJM199510193331603
[150] M. Matloubian, R. J. Concepcion and R. Ahmed, "CD4 $4^{+}$ $\mathrm{T}$ Cells Are Required to Sustain $\mathrm{CD}^{+}$Cytotoxic T-Cell Responses During Chronic Viral Infection," Journal of Virology, Vol. 68, No. 12, 1994, pp. 8056-8063.

[151] M. E. Dudley, J. R. Wunderlich, J. C. Yang, R. M. Sherry, S. L. Topalian, N. P. Restifo, R. E. Royal, U. Kammula, D. E. White, S. A. Mavroukakis, L. J. Rogers, G. J. Gracia, S. A. Jones, D. P. Mangiameli, M. M. Pelletier, J. Gea-Banacloche, M. R. Robinson, D. M. Berman, A. C. Filie, A. Abati and S. A. Rosenberg, "Adoptive Cell Transfer Therapy Following Non-Myeloablative but Lymphodepleting Chemotherapy for the Treatment of Patients with Refractory Metastatic Melanoma," Journal of Clinical Oncology, Vol. 23, No. 10, 2005, pp. 2346-2357. doi:10.1200/JCO.2005.00.240

[152] M. E. Dudley, J. C. Yang, R. Sherry, M. S. Hughes, R. Royal, U. Kammula, P. F. Robbins, J. Huang, D. E. Citrin, S. F. Leitman, J. Wunderlich, N. P. Restifo, A. Thomasian, S. G. Downey, F. O. Smith, J. Klapper, K. Morton, C. Laurencot, D. E. White and S. A. Rosenberg, "Adoptive Cell Therapy for Patients With Metastatic Melanoma: Evaluation of Intensive Myeloablative Chemoradiation Preparative Regimens," Journal of Clinical Oncology, Vol. 26, No. 2, 2008, pp. 5233-5239. doi:10.1200/JCO.2008.16.5449

[153] S. A. Rosenberg and M. E. Dudley, “Adoptive Cell Therapy for the Treatment of Patients with Metastatic Melanoma," Current Opinion in Immunology, Vol. 21, No. 2, 2009, pp. 233-240. doi:10.1016/j.coi.2009.03.002

[154] S. A. Rosenberg, J. C. Yang, R. M. Sherry, U. S. Kammula, M. S. Hughes, G. Q. Phan, D. E. Citrin, N. P. Restifo, P. F. Robbins, J. R. Wunderlich, K. E. Morton, C. M. Laurencot, S. M. Steinberg, D. E. White and M. E. Dudley, "Durable Complete Responses in Heavily Pretreated Patients with Metastatic Melanoma Using T-Cell Transfer Immunotherapy," Clinical Cancer Research, Vol. 17, No. 13, 2011, pp. 4550-4557. doi:10.1158/1078-0432.CCR-11-0116

[155] S. P. Kerkar, L. Sanchez-Perez, S. Yang, Z. Borman, P. Muranski, Y. Ji, D. Chinnasamy, A. D. Kaiser, C. Hinrichs, C. S. Klebanoff, C. D. Scott, L. Gattinoni, R. A. Morgan, S. A. Rosenberg and N. P. Restifo, "Genetic Engineering of Murine $\mathrm{CD}^{+}$and $\mathrm{CD}^{+} \mathrm{T}$ Cells for Pre-clinical Adoptive Immunotherapy Studies," Journal of Immunotherapy, Vol. 34, No. 4, 2011, pp. 343-352. doi:10.1097/CJI.0b013e3182187600

[156] J. D. Abad, C. Wrzensinski, W. Overwijk, M. A. de Witte, A. Jorritsma, C. Hsu, L. Gattinoni, C. J. Cohen, C. M. Paulos, D. C. Palmer, J. B. Haanen, T. N. Schumacher, S. A. Rosenberg, N. P. Restifo and R. A. Morgan, "T-Cell Receptor Gene Therapy of Established Tumors in a Murine Melanoma Model," Journal of Immunotherapy, Vol. 31, No. 1, 2008, pp. 1-6. doi:10.1097/CJI.0b013e31815c193f

[157] R. A. Morgan, M. E. Dudley, J. R. Wunderlich, M. S. Hughes, J. C. Yang, R. M. Sherry, R. E. Royal, S. L. Topalian, U. D. Kammula, N. P. Restifo, Z. Zheng, A. Nahvi, C. R. de Vries, L. J. Rogers-Freezer, S. A. Mavroukakis and S. A. Rosenberg, "Cancer Regression in Patients after Transfer of Genetically Engineered Lymphocytes," Science, Vol. 314, No. 5796, 2006, pp. 126-129. 
$\underline{\text { doi: } 10.1126 / \text { science. } 1129003}$

[158] L. A. Johnson, R. A. Morgan, M. E. Dudley, L. Cassard, J. C. Yang, M. S. Hughes, U. S. Kammula, R. E. Royal, R. M. Sherry, J. R. Wunderlich, C.-C. R. Lee, N. P. Restifo, S. L. Schwarz, A. P. Cogdill, R. J. Bishop, H. Kim, C. C. Brewer, S. F. Rudy, C. van Waes, J. L. Davis, A. Mathur, R. T. Ripley, D. A. Nathan, C. M. Laurencot and S. A. Rosenberg, "Gene Therapy with Human and Mouse T-Cell Receptors Mediates Cancer Regression and Targets Normal Tissues Expressing Cognate Antigen," Blood, Vol. 114, No. 3, 2009, pp. 535-546. doi:10.1182/blood-2009-03-211714

[159] Q. Zhou, I. C. Schneider, I. Edes, A. Honegger, P. Bach, K. Schonfeld, A. Schambach, W. S. Wels, S. Kneissl, W. Uckert and C. J. Buchholz, "T-Cell Receptor Gene Transfer Exclusively to Human $\mathrm{CD}^{+}$Cells Enhances Tumor Cell Killing," Blood, Vol. 120, No. 22, 2012, pp. 43344342. doi:10.1182/blood-2012-02-412973

[160] B. A. Pockaj, R. M. Sherry, J. P. Wei, J. R. Yannelli, C. S. Carter, S. F. Leitman, J. A. Carasquillo, S. M. Steinberg, S. A. Rosenberg and J. C. Yang, "Localization of ${ }^{111}$ Indium-Labeled Tumor Infiltrating Lymphocytes to Tumor in Patients Receiving Adoptive Immunotherapy. Augmentation with Cyclophosphamide and Correlation with Response," Cancer, Vol. 73, No. 6, 1994, pp. 1731- 1737. doi:10.1002/1097-0142(19940315)73:6<1731::AID-CNC R2820730630>3.0.CO;2-H

[161] M. H. Kershaw, G. Wang, J. A. Westwood, R. K. Pachynski, H. L. Tiffany, F. M. Marincola, E. Wang, H. A. Young, P. M. Murphy and P. Hwu, "Redirecting Migration of T Cells to Chemokine Secreted from Tumors by Genetic Modification with CXCR2," Human Gene Therapy, Vol. 13, No. 16, 2002, pp. 1971-1980. doi: $10.1089 / 10430340260355374$

[162] D. J. Waugh and C. Wilson, "The Interleukin-8 Pathway in Cancer," Clinical Cancer Research, Vol. 14, No. 21, 2008, pp. 6735-6741. doi:10.1158/1078-0432.CCR-07-4843

[163] W. Peng, Y. Ye, B. A. Rabinovich, C. Liu, Y. Lou, M. Zhang, M. Whittington, Y. Yang, W. W. Overwijk, G. Lizee and P. Hwu, "Transduction of Tumor-Specific T cells with CXCR2 Chemokine Receptor Improves the Migration to Tumor and Antitumor Immune Responses," Clinical Cancer Research, Vol. 16, No. 22, 2010, pp. 5458-5468. doi:10.1158/1078-0432.CCR-10-0712

[164] J. A. Craddock, A. Lu, A. Bear, M. Pule, M. K. Brenner, C. M. Rooney and A. E. Foster, "Enhanced Tumor Trafficking of GD2 Chimeric Antigen Receptor T Cells by Expression of the Chemokine Receptor CCR2b," Journal of Immunotherapy, Vol. 33, No. 8, 2010, pp. 780-788. doi:10.1097/CJI.0b013e3181ee6675

[165] E. K. Moon, C. Carpenito, J. Sun, L. C. Wang, V. Kapoor, J. Predina, D. J. Powel, Jr., J. L. Riley, C. H. June and S. M. Albelda, "Expression of a Functional CCR2 Receptor Enhances Tumor Localization and Tumor Eradication by Retargeted Human T Cells Expressing a Mesothelin-Specific Chimeric Antibody Receptor," Clinical Cancer Research, Vol. 17, No. 14, 2011, pp. 4719-4730. doi:10.1158/1078-0432.CCR-11-0351
[166] T. L. Darrow, Z. Wahab, M. A. Quinn-Allen and H. F. Seigler, "Human Melanoma-Mediated Inhibition of Autologous CD4 ${ }^{+}$Helper Tumor-Infiltrating Lymphocyte Growth in Vitro," Cancer, Vol. 69, No. 7, 1992, pp. 1843-1849. doi:10.1002/1097-0142(19920401)69:7<1843::AID-CNC R2820690728>3.0.CO;2-D

[167] V. Singh, Q. Ji, L. Feigenbaum, R. M. Leighty and A. A. Hurwitz, "Melanoma Progression despite Infiltration by in Vivo-Primed TRP-2 Specific T Cells," Journal of Immunotherapy, Vol. 32, No. 2, 2009, pp. 129-139. doi:10.1097/CJI.0b013e31819144d7

[168] M. Ahmadzadeh, L. A. Johnson, B. Heemskerk, J. R. Wunderlich, M. E. Dudley, D. E. White and S. A. Rosenberg, "Tumor Antigen-Specific CD8 T Cells Infiltrating the Tumor Express High Levels of PD-1 and Are Functionally Impaired," Blood, Vol. 114, No. 8, 2009, pp. 1537-1544. doi:10.1182/blood-2008-12-195792

[169] K. Bachmaier, C. Krawczyk, I. Kozieradzki, Y. Y. Kong, T. Sasaki, A. Oliviera-dos-Santos, S. Mariathasan, D. Bouchard, A. Wakeham, A. Itie, J. Le, P. S. Ohashi, I. Sarosi, H. Nishina, S. Lipkowitz and J. M. Penninger, "Negative Regulation of Lymphocyte Activation and Autoimmunity by the Molecular Adaptor Cbl-b," Nature, Vol. 403, No. 6766, 2000, pp. 211-216. doi: $10.1038 / 35003228$

[170] Y. J. Chiang, H. K. Kole, K. Brown, M. Naramura, S. Fukuhara, F. J. Hu, I. K. Jang, J. S. Gutkind, E. Shevach and H. Gu, "Cbl-b Regulates the CD28 Dependence of T-Cell Activation," Nature, Vol. 403, No. 6766, 2000, pp. 216-220. doi:10.1038/35003235

[171] E. A. Wohlfert, L. Gorelik, R. Mittler, R. A. Flavell and R. B. Clark, "Cutting Edge: Deficiency in the E3 Ubiquitin Ligase Cbl-b Results in a Multifunctional Defect in T Cell TGF-Beta Sensitivity in Vitro and in Vivo," The Journal of Immunology, Vol. 176, No. 3, 2006, pp. 13161320.

[172] R. Hinterleitner, T. Gruber, C. Pfeifhofer-Obermair, C. Lutz-Nicoladoni, A. Tzankov, M. Schuster, J. M. Penninger, H. Loibner, G. Lametschwandtner, D. Wolf and G. Baier, "Adoptive Transfer of siRNA Cblb-Silenced CD8 ${ }^{+}$ T Lymphocytes Augments Tumor Vaccine Efficacy in a B16 Melanoma Model," PLoS One, Vol. 7, No. 9, 2012, Article ID: e44295. doi:10.1371/journal.pone.0044295

[173] K. Iwamura, T. Kato, Y. Miyahara, H. Naota, J. Mineno, H. Ikeda and H. Shiku, "SiRNA-Mediated Silencing of PD-1 Ligands Enhances Tumor-Specific Human T-Cell Effector Functions," Gene Therapy, Vol. 19, No. 10, 2012, pp. 959-966. doi:10.1038/gt.2011.185

[174] C. Hsu, M. S. Hughes, Z. Zheng, R. B. Bray, S. A. Rosenberg and R. A. Morgan, "Primary Human T Lymphocytes Engineered with a Codon-Optimized IL-15 Gene Resist Cytokine Withdrawal-Induced Apoptosis and Persist Long-Term in the Absence of Exogenous Cytokine," The Journal of Immunology, Vol. 175, No. 11, 2005, pp. 7226-7234.

[175] J. Charo, S. E. Finkelstein, N. Grewal, N. P. Restifo, P. F. Robbins and S. A. Rosenberg, "Bcl-2 Overexpression Enhances Tumor-Specific T-Cell Survival," Cancer Research, Vol. 65, No. 5, 2005, pp. 2001-2008. doi:10.1158/0008-5472.CAN-04-2006 
[176] M. T. Stephan, V. Ponomarev, R. J. Brentjens, A. H. Chang, K. V. Dobrenkov, G. Heller and M. Sadelain, "T Cell-Encoded CD80 and 4-1BBL Induce Auto- and Transcostimulation, Resulting in Potent Tumor Rejec- tion," Nature Medicine, Vol. 13, No. 12, 2007, pp. 14401449. doi: $10.1038 / \mathrm{nm} 1676$ 